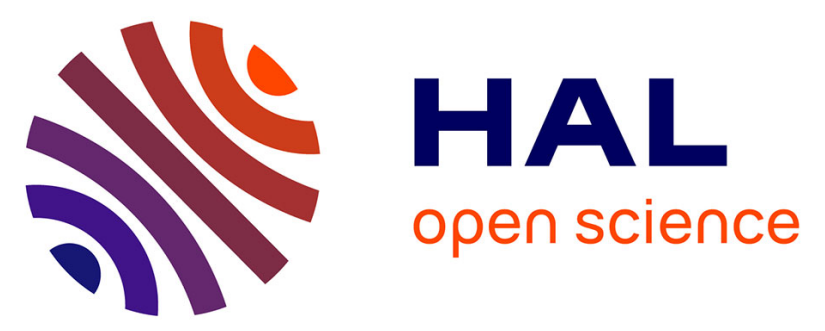

\title{
Low-dose hyper-radiosensitivity of progressive and regressive cells isolated from a rat colon tumour: impact of DNA repair.
}

Charles Thomas, Josiane Charrier, Catherine Massart, Michel Cherel, Bernard Fertil, Jacques Barbet, Nicolas Foray

\section{To cite this version:}

Charles Thomas, Josiane Charrier, Catherine Massart, Michel Cherel, Bernard Fertil, et al.. Lowdose hyper-radiosensitivity of progressive and regressive cells isolated from a rat colon tumour: impact of DNA repair.. International Journal of Radiation Biology, 2008, 84 (7), pp.533-548. 10.1080/09553000802195331 . inserm-00831027

\section{HAL Id: inserm-00831027 https://www.hal.inserm.fr/inserm-00831027}

Submitted on 6 Jun 2013

HAL is a multi-disciplinary open access archive for the deposit and dissemination of scientific research documents, whether they are published or not. The documents may come from teaching and research institutions in France or abroad, or from public or private research centers.
L'archive ouverte pluridisciplinaire HAL, est destinée au dépôt et à la diffusion de documents scientifiques de niveau recherche, publiés ou non, émanant des établissements d'enseignement et de recherche français ou étrangers, des laboratoires publics ou privés. 
This article was downloaded by:[Joint ILL - Institute Laue-Langevin]

On: 28 July 2008

Access Details: [subscription number 789347735]

Publisher: Informa Healthcare

Informa Ltd Registered in England and Wales Registered Number: 1072954

Registered office: Mortimer House, 37-41 Mortimer Street, London W1T 3JH, UK

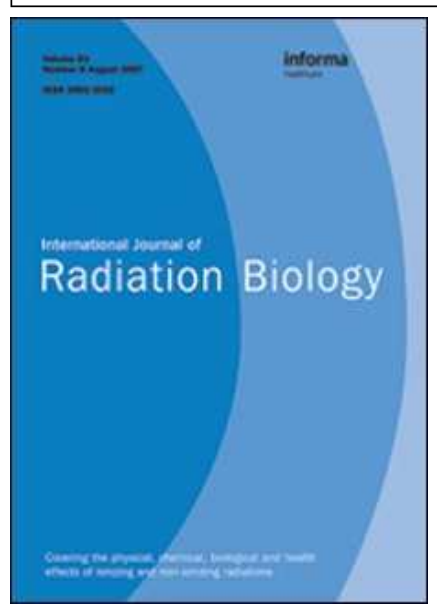

\section{International Journal of Radiation Biology}

Publication details, including instructions for authors and subscription information: http://www.informaworld.com/smpp/title content=t713697337

Low-dose hyper-radiosensitivity of progressive and regressive cells isolated from a rat colon tumour: Impact of DNA repair

Charles Thomas ${ }^{a b}$; Josiane Charrier ${ }^{c}$; Catherine Massart ${ }^{b}$; Michel Cherel ${ }^{a c}$; Bernard Fertil ${ }^{d}$; Jacques Barbet ${ }^{a}$; Nicolas Foray ${ }^{b}$

a Institut National de la Santé et de la Recherche Médicale (INSERM), U601, Nantes

b INSERM, Grenoble

c Centre R. Gauducheau, Nantes

d INSERM, U678, Paris, France

Online Publication Date: 01 January 2008

To cite this Article: Thomas, Charles, Charrier, Josiane, Massart, Catherine, Cherel, Michel, Fertil, Bernard, Barbet, Jacques and Foray, Nicolas (2008) 'Low-dose hyper-radiosensitivity of progressive and regressive cells isolated from a rat colon tumour: Impact of DNA repair', International Journal of Radiation Biology, 84:7, $533 \tilde{N} 548$

To link to this article: DOI: $10.1080 / 09553000802195331$

URL: http://dx.doi.org/10.1080/09553000802195331

\section{PLEASE SCROLL DOWN FOR ARTICLE}

Full terms and conditions of use: http://www.informaworld.com/terms-and-conditions-of-access.pdf

This article maybe used for research, teaching and private study purposes. Any substantial or systematic reproduction, re-distribution, re-selling, loan or sub-licensing, systematic supply or distribution in any form to anyone is expressly forbidden.

The publisher does not give any warranty express or implied or make any representation that the contents will be complete or accurate or up to date. The accuracy of any instructions, formulae and drug doses should be independently verified with primary sources. The publisher shall not be liable for any loss, actions, claims, proceedings, demand or costs or damages whatsoever or howsoever caused arising directly or indirectly in connection with or arising out of the use of this material. 


\title{
Low-dose hyper-radiosensitivity of progressive and regressive cells isolated from a rat colon tumour: Impact of DNA repair
}

\author{
CHARLES THOMAS ${ }^{1,2}$, JOSIANE CHARRIER ${ }^{3}$, CATHERINE MASSART $^{2}$, \\ MICHEL CHEREL ${ }^{1,3}$ BERNARD FERTIL $^{4}$, JACQUES BARBET ${ }^{1}$, \& NICOLAS FORAY ${ }^{2}$ \\ ${ }^{1}$ Institut National de la Santé et de la Recherche Médicale (INSERM), U601, Nantes, ${ }^{2}$ INSERM, U836, European \\ Synchrotron Radiation Facility, Grenoble, ${ }^{3}$ Centre R. Gauducheau, Nantes, and ${ }^{4}$ INSERM, U678, Paris, France
}

(Received 8 December 2007; revised 28 March 2008; accepted 3 May 2008)

\begin{abstract}
Purpose: To ask whether highly metastatic sublines show more marked low-dose hyper-radiosensitivity (HRS) response than poorly metastatic ones.

Materials and methods: The progressive (PRO) subline showing tumourigenicity and metastatic potential and the regressive (REG) subline showing neither tumourigenicity nor metastatic potential were both isolated from a parental rat colon tumour. Clonogenic survival, micronuclei and apoptosis, cell cycle distribution, DNA single- (SSB) and double-strand breaks (DSB) induction and repair were examined.

Results: HRS phenomenon was demonstrated in PRO subline. Before irradiation, PRO cells show more spontaneous damage than REG cells. After 0.1 Gy, PRO cells displayed: (i) More DNA SSB 15 min post-irradiation, (ii) more unrepaired DNA DSB processed by the non-homologous end-joining (NHEJ) and by the RAD51-dependent recombination pathways, (iii) more micronuclei, than REG cells while neither apoptosis nor p53 phosphorylation nor cell cycle arrest was observed in both sublines.

Conclusions: HRS response of PRO subline may be induced by impairments in NHEJ repair that targets $\mathrm{G}_{1}$ cells and RAD51-dependent repair that targets $S-G_{2} / M$ cells. The cellular consequences of such impairments are a failure to arrest in cell cycle, the propagation of damage through cell cycle, mitotic death but not p53-dependent apoptosis. Tumourigenic cells with high metastatic potential may preferentially show HRS response.
\end{abstract}

Keywords: Low-dose hyper-radiosensitivity, DNA repair, cell cycle, cell death, micrometastases

\section{Introduction}

Among each type of tumour, the required tumour lethal dose varies most commonly by a two-three factor (Friedman 1975). Radiobiological features of such intra-tumour heterogeneity have been recently highlighted by in vitro studies supporting that cells within a given tumour cell line show low-dose hyperradiosensitivity (HRS) that is replaced by induced radioresistance (IRR) at a cell-line-dependent threshold of 10-30 cGy. Such a conclusion was reached after analyzing more than 40 tumour cell lines (Skov 1999, Joiner et al. 2001, Marples et al. 2004). Micrometastases elicit higher genetic instability and heterogeneity than primary tumours
(Tortola et al. 2001, Klein et al. 2002). However, whether micrometastases may preferentially show more HRS response than primary tumours is not well documented. In addition, only few models of micrometastases or spontaneous metastatic clones deriving from the same parental tumor cell line are available.

By using seven highly and poorly metastatic clones derived from the same parental human melanoma cell line, we have previously shown that the more the clones show marked HRS response, the more the clones are metastatic (Thomas et al. 1997). HRS was also reported in human metastatic skin nodules (Harney et al. 2004). Hence, these findings suggest that the higher the HRS response, the higher the

Correspondence: N. Foray, INSERM U836, ESRF, Rue Horowitz, 38043 Grenoble, France. Tel: +33476882541. Fax +334 76882885.

E-mail: foray@esrf.fr

This paper is dedicated to Anna Buronfosse.

ISSN 0955-3002 print/ISSN 1362-3095 online (c) 2008 Informa UK Ltd.

DOI: $10.1080 / 09553000802195331$ 
tumourigenicity. Besides, it is noteworthy that HRS is not a common finding in human normal cells (Slonina et al. 2007). The fact that highly metastatic cells may preferentially show more HRS response than poorly metastatic ones suggests that HRS response should be considered more carefully in the radiotherapy of micrometastases (Thomas et al. 2007).

Although a number of molecular models have been proposed, mechanisms of HRS are still unclear (Skov 1999, Joiner et al. 2001, Marples et al. 2004). It has been suggested that HRS may depend upon changes in chromatin conformation (Joiner et al. 2001), failure of the ATM-dependent $\mathrm{G}_{2} / \mathrm{M}$ checkpoint (Marples et al. 2004), DNA repair defects (Vaganay-Juery et al. 2000, Short et al. 2005) and/or induction of p53-dependent apoptosis (Enns et al. 2004). The DNA repair field has recently progressed, especially for DNA DSB. Notably, impairments of the major DNA DSB repair pathways, the non-homologous end-joining (NHEJ) and the RAD51-dependent recombination, result in high radiosensitivity and cancer proneness, respectively (Joubert \& Foray, 2006, Joubert et al. 2008). Finally, a functional and temporal hierarchy between ATMdependent phosphorylation events occurring early after irradiation has been demonstrated: such phosphorylations may determine success of DNA repair, cell cycle arrests and cell death (Foray et al. 2003). Here, by using such endpoints, we examined whether HRS response is higher in tumorigenic cells with high metastatic potential than in non-tumorigenic cells. The previously described PRO and REG sublines that derived from the same parental rat colon tumour were chosen as a model (Martin et al. 1983).

\section{Materials and methods}

\section{Cells and irradiation}

PRO and REG sublines were kindly provided by $\mathrm{Dr}$ F. Martin (Dijon, France). PRO and REG sublines were isolated from the parental tumour cell line DHD-K12, established from dimethylhydrazine-induced colon carcinoma in syngeneic BDIX rats (Martin et al. 1983). PRO and REG sublines have been isolated according to their sensitivity to trypsinmediated detachment from plastic surface (PRO subline is more trypsin-resistant than REG subline). PRO and REG cells show different immunogenicity and tumorigenicity in syngeneic hosts. When grafted subcutaneously in BDIX rats, REG cells produced regressive tumours disappearing within 3-4 weeks while PRO cells produced progressive tumours in $60 \%$ of animals (Martin et al. 1983). Metastases to lungs, kidney or lymph nodes were observed in more than $50 \%$ of rats in which PRO tumour was either allowed to grow for four months or excised 2-4 weeks after inoculation (Martin et al. 1983). In contrast, neither syngeneic BDIX rats nor nude mice that are inoculated with REG cells produced metastases (Martin et al. 1983). PRO and REG sublines were cultured in Roswell Park Memorial Institute (RPMI) 1640 medium with $2 \mathrm{mM}$ glutamine, $10 \%$ decomplemented fetal bovine serum and antibiotics (1\% penicillin, streptomycin) (GibcoInvitrogen-France, Cergy-Pontoise, France). Cells were mycoplasma-free and maintained at $37^{\circ} \mathrm{C}$ at $5 \%$ $\mathrm{CO}_{2}$ for no more than five passages. For all the assays described below, confluent PRO and REG cultures were softly detached with $0.025 \%$ trypsin and $0.02 \%$ ethylenediaminetetraacetic acid (EDTA) (Gibco-Invitrogen-France, Cergy-Pontoise, France) to obtain single cell suspensions. Irradiations were performed either with ${ }^{60} \mathrm{Co} \gamma$-rays at a dose rate of $0.5 \mathrm{~Gy} \cdot \mathrm{min}^{-1}$ (clonogenic assay, comet assay) or with $\mathrm{X}$-rays produced by two irradiators (immunofluorescence and cell cycle assays): a Philips BV212 mobile surgical system $(100 \mathrm{kV}, 3 \mathrm{~mA})$ delivering 0.1 Gy at a dose rate of $0.17 \mathrm{~Gy} \cdot \mathrm{min}^{-1}$ and a clinical irradiator $(200 \mathrm{kV}, 20 \mathrm{~mA})$ delivering $6 \mathrm{~Gy}$ at a dose rate of $1.25 \mathrm{~Gy} \cdot \mathrm{min}^{-1}$. It is noteworthy that ${ }^{60} \mathrm{Co} \gamma$-rays, $100 \mathrm{kV}$ and $200 \mathrm{kV}$ $\mathrm{X}$-rays induce the same DNA DSB induction rate (data not shown).

\section{Clonogenic survival assay}

Clonogenic survival was assessed as previously described (Thomas et al. 1997). Briefly, 500 cells were seeded and irradiated 2 or $24 \mathrm{~h}$ after plating with doses ranging from 0.05-6 Gy. Colonies were fixed and stained with standard crystal violet solution (Sigma-Aldrich-France, L'Isle d'Abeau, France) incubation without change of medium. Only colonies showing more than 50 cells were considered. Plating efficiencies of unirradiated REG and PRO cells were $30 \pm 1.4 \%$ (mean \pm SEM (standard error of the mean), $n=21$ ) and $23 \pm 1 \%$ (mean \pm SEM, $n=23$ ), respectively. In order to examine whether, before irradiation, cellular proliferation may impact upon HRS response, multiplicity assay was applied. To this aim, cells were fixed and stained with crystal violet $24 \mathrm{~h}$ after plating: in such conditions, the cell multiplicity (i.e., the number of cells per colony-forming unit) was found to be closed to one.

\section{Survival curves analysis}

Surviving fractions (SF) were fitted to three models: The one population linear-quadratic (LQ) model, the induced repair (IR) model (Lambin et al. 1994) 
and the two populations linear-quadratic (2-pop LQ) model (Thomas et al. 1997) defined by, respectively:

$$
\begin{aligned}
& \text { (1) } \mathrm{SF}(\mathrm{D})=\mathrm{e}^{-\left(\alpha \cdot \mathrm{D}+\beta \cdot \mathrm{D}^{2}\right)} \\
& \text { (2) } \mathrm{SF}(\mathrm{D})=\mathrm{e}^{-\alpha_{\mathrm{r}}\left[1+\left(\frac{\alpha_{\mathrm{s}}}{\alpha_{\mathrm{r}}}-1\right) \cdot \mathrm{e}^{\mathrm{D}}\right]} \cdot \mathrm{D}-\beta_{\mathrm{r}} \cdot \mathrm{D}^{2} \\
& \text { (3) } \mathrm{SF}(\mathrm{D})=(1-\lambda) \cdot \mathrm{e}^{-\alpha_{\mathrm{s}} \cdot \mathrm{D}}+\lambda \cdot \mathrm{e}^{-\left(\alpha_{\mathrm{r}} \cdot \mathrm{D}+\beta_{\mathrm{r}} \cdot \mathrm{D}^{2}\right)}
\end{aligned}
$$

The IR model is a modified version of the LQ model in which the $\alpha$ term is dependent on dose (D): at very low doses, $\alpha$ is large, and it decreases with increasing dose in an exponential manner at a rate determined by a constant $d_{c}$. The parameter $\alpha_{s}$ represents the initial slope of the curve at very low doses, $\alpha_{r}$ represents the value extrapolated from the conventional high-doses response, $d_{c}$ represents the dose that induced the change from HRS to IRR. The occurrence of HRS/IRR is mathematically deduced from $\alpha_{\mathrm{s}}$ and $\alpha_{\mathrm{r}}$ values that do not coincide and $\mathrm{d}_{\mathrm{c}}$ values significantly greater than zero (Table I). With regard to the 2-pop LQ model that assumed the existence of two subpopulations of cells with different radiosensitivity, the $\lambda$ parameter represents the proportion of radioresistant cells. The $\alpha_{\mathrm{s}}$ parameter is linked to the radiosensitive subpopulation. The $\alpha_{\mathrm{r}}, \beta_{\mathrm{r}}$ parameters are linked to the radioresistant subpopulation. All the survival data were fitted by using the JMP Software (version 2.0.5, SAS Institute, Cary, NC, USA).

\section{Alkaline comet assay}

The experimental protocol for the alkaline comet assay was previously described (Alapetite et al. 1996) and was applied here with minor modifications. Briefly, cells embedded in agarose (Sigma) were irradiated $2 \mathrm{~h}$ after plating on slides that were maintained on ice for at least $30 \mathrm{~min}$ before irradiation and protected from direct natural light during all following steps. For the assessment of initial DNA SSB, slides were immersed immediately after irradiation at doses ranging from $0.05-6$ Gy for $1 \mathrm{~h}$ in lysis solution $(2.5 \mathrm{M} \mathrm{NaCl}, 100 \mathrm{mM}$ EDTA, $10 \mathrm{mM}$ tris-hydroxymethylaminomethane, $1 \% \mathrm{~N}$ laurylsarcosine, $1 \%$ Triton X-100, 10\% dimethylsulfoxide, $\mathrm{pH} 10,4^{\circ} \mathrm{C}$ ) (Sigma-Aldrich-France, L'Isle d'Abeau, France). For the assessment of residual DNA SSB, slides were incubated after irradiation at 0.1 and $6 \mathrm{~Gy}$ in complete medium at $37^{\circ} \mathrm{C}$ for $15 \mathrm{~min}, 1$ and $14 \mathrm{~h}$ before lysis. Slides were transferred to electrophoresis box containing alkaline buffer (300 mM NaOH, $1 \mathrm{mM}$ EDTA, pH 13) (Sigma-Aldrich-France, L'Isle d'Abeau, France) for $40 \mathrm{~min}$ to allow DNA unwinding. Electrophoresis was performed for $20 \mathrm{~min}(25 \mathrm{~V}, 300 \mathrm{~mA})$. Slides were rinsed twice for $5 \mathrm{~min}$ with neutralization buffer

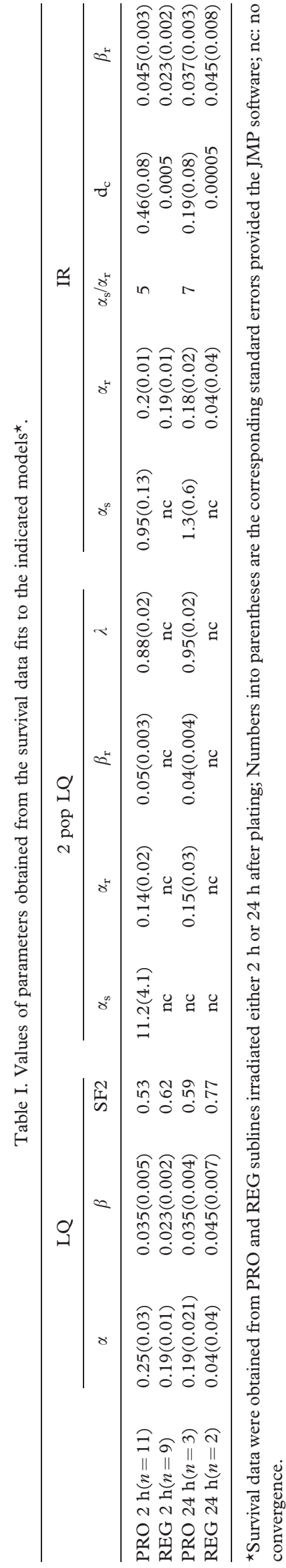


(0.4 M Tris, $\mathrm{pH}$ 7.5), stained with $8 \mathrm{ng} \cdot \mu \mathrm{l}^{-1}$ ethidium bromide (Sigma-Aldrich-France, L'Isle d'Abeau, France) and kept at $4{ }^{\circ} \mathrm{C}$. Comets were observed with Leica fluorescence microscope and analyzed with the image analysis Komet software (Kinetic imaging 4.0, Andor technology, South Windsor, CT, USA). Comets were evaluated by tail moment defined as product of tail DNA percent and tail length. The tail moment of irradiated cells was divided by the tail moment of unirradiated cells to provide the normalized tail moment. Cells were considered as highly damaged cells (HDC) if the normalized tail moment was higher than $90 \%$. In each experiment, 15 comets per slide were randomly captured at constant gel depth, by avoiding gel edge and superimposed comets. Each experiment was replicated three times and 45 comets were considered per dose.

\section{Immunofluorescence assay}

This assay already described (Foray et al. 2003) was applied with minor modifications. Briefly, $5 \times 10^{5}$ cells were seeded on slides and incubated for $24 \mathrm{~h}$ in complete medium at $37^{\circ} \mathrm{C}$. After irradiation at 0.1 $\mathrm{Gy}$, dishes were incubated at $37^{\circ} \mathrm{C}$ for $10 \mathrm{~min}, 1 \mathrm{~h}$, $24 \mathrm{~h}$ and $48 \mathrm{~h}$ while after irradiation at $6 \mathrm{~Gy}$, dishes were incubated for $24 \mathrm{~h}$ only. Cells were fixed in paraformaldehyde solution for $15 \mathrm{~min}$ at room temperature and permeabilized for $90 \mathrm{~s}$ at $4^{\circ} \mathrm{C}$ in lysis solution (20 mM 4-(2-hydroxyethyl)-1-piperazine ethanesulfonic acid (HEPES) (pH 7.4), $50 \mathrm{mM}$ $\mathrm{NaCl}, 3 \mathrm{mM} \mathrm{MgCl}$, $300 \mathrm{mM}$ sucrose, $0.5 \%$ Triton $\mathrm{X}-100$ ) (Sigma-Aldrich-France, L'Isle d'Abeau, France). Primary antibody incubations were performed for $40 \mathrm{~min}$ at $37^{\circ} \mathrm{C}$. Anti- $p H 2 \mathrm{AX}^{\text {ser139 }}$ antibody (\#05636; Upstate Biotechnology-Euromedex, Mundolsheim, France) was used at 1:800. Anti-pATM ${ }^{\text {ser1981 }}$ (\#2888; Abcam, Cambridge, UK), -pDNA-PK $K^{\text {thr2609 }}$ (\#ab4194; Abcam, Cambridge, UK), $-p H 3^{\text {ser10 }}$ (\#ab14955; Abcam, Cambridge, UK), -MRE11 (\#56211; Abcys, Paris, France) and $-p P 53^{\operatorname{ser} 15}$ (\#9284; Cell Signalling, Beverly, USA), and -RAD51 (\#8349; Santa-CruzBiotechnologies, Santa-Cruz, USA) were used at $1: 100$. Incubations with anti-mouse fluorescein (green) or rhodamin (red) secondary antibodies were performed at $1: 100$ at $37^{\circ} \mathrm{C}$ for $20 \mathrm{~min}$. Slides were mounted in 4',6-diamidino-2-phenylindole (DAPI)stained Vectashield (Abcys, Paris, France) and 100 cells per slide were examined with Olympus fluorescence microscope. DAPI staining permitted to indirectly evaluate yield of $G_{1}$ cells (nuclei with homogeneous DAPI staining), $S$ cells (nuclei showing numerous $\mathrm{pH} 2 \mathrm{AX}$ foci), $\mathrm{G}_{2}$ cells (nuclei with heterogeneous DAPI staining) and metaphase (visible chromosomes). DAPI staining permitted also to quantify the percentage of cells with micronuclei by examining 100 cells at least.

\section{Cell cycle analysis}

PRO and REG cells were seeded at $5 \times 10^{5}$ cells per dish and showed similar doubling time of about $36 \mathrm{~h}$. Twenty-four hours after plating, cells were irradiated at 0.1 and $6 \mathrm{~Gy}$. Fifteen $\mathrm{min}, 1 \mathrm{~h}, 6 \mathrm{~h}$ and $24 \mathrm{~h}$ after irradiation at $0.1 \mathrm{~Gy}$ and $15 \mathrm{~min}$ and $24 \mathrm{~h}$ after irradiation at $6 \mathrm{~Gy}$, cells were trypsinized, fixed in $70 \%$ ethanol and stored at $-20^{\circ} \mathrm{C}$. At least $10^{4}$ fixed cells treated with $10 \mu \mathrm{g} \cdot \mathrm{ml}^{-1}$ RNAse A and $20 \mu \mathrm{g} \cdot \mathrm{ml}^{-1}$ propidium iodide (Sigma-AldrichFrance, L'Isle d'Abeau, France) were analyzed using cytometer (Beckton Dickinson, Pont-de-Claix, France). Cell cycle distribution was quantified with WinMDI software (Scripps-Research-Institute, La Jolla, USA).

\section{Results}

$H R S$ response and cell cycle distribution

Since it was suggested that $G_{2}$ phase cells may explain the HRS response (Marples et al. 2004), cell cycle distribution and cell survival were both examined in PRO/REG cells. As a first step, the HRS response was examined by irradiating $\mathrm{PRO} /$ REG cells $2 \mathrm{~h}$ after plating. HRS response varied greatly according to the different experiments. PRO and REG cells showed HRS response in 9 among 11 and 3 among 9 independent experiments, respectively (Figure 1A, 1B). These data suggest that PRO cells display more HRS response than REG cells when cells are irradiated $2 \mathrm{~h}$ after plating. Twenty-four hours after plating, PRO cells also showed HRS response whereas REG cells did not. Moreover, the initial part of the survival curve (i.e., the HRS response) was similar in PRO cells whether irradiated $2 \mathrm{~h}$ or $24 \mathrm{~h}$ after plating (Figure 1C). Survival data shown in Figure 1C were fitted to the LQ, 2-pop LQ and IR models. It appeared that the HRS response in PRO cells was better described by the IR model than by the 2-pop LQ model. This was notably verified in the lowdose range for PRO cells irradiated $24 \mathrm{~h}$ after plating in which the $\alpha_{s}$ parameter of the 2-pop LQ model was unable to be determined by the fitting analysis (Table I). PRO cells irradiated $2 \mathrm{~h}$ or $24 \mathrm{~h}$ after plating showed $\alpha_{\mathrm{s}} / \alpha_{\mathrm{r}}$ ratios of 5 and 7 , respectively (Table I). Thus, the HRS response in PRO cells irradiated $2 \mathrm{~h}$ after plating was similar to that obtained in PRO cells irradiated $24 \mathrm{~h}$ after plating. By contrast, REG cells did not show any significant HRS response, whatever the time after plating (Table I). 

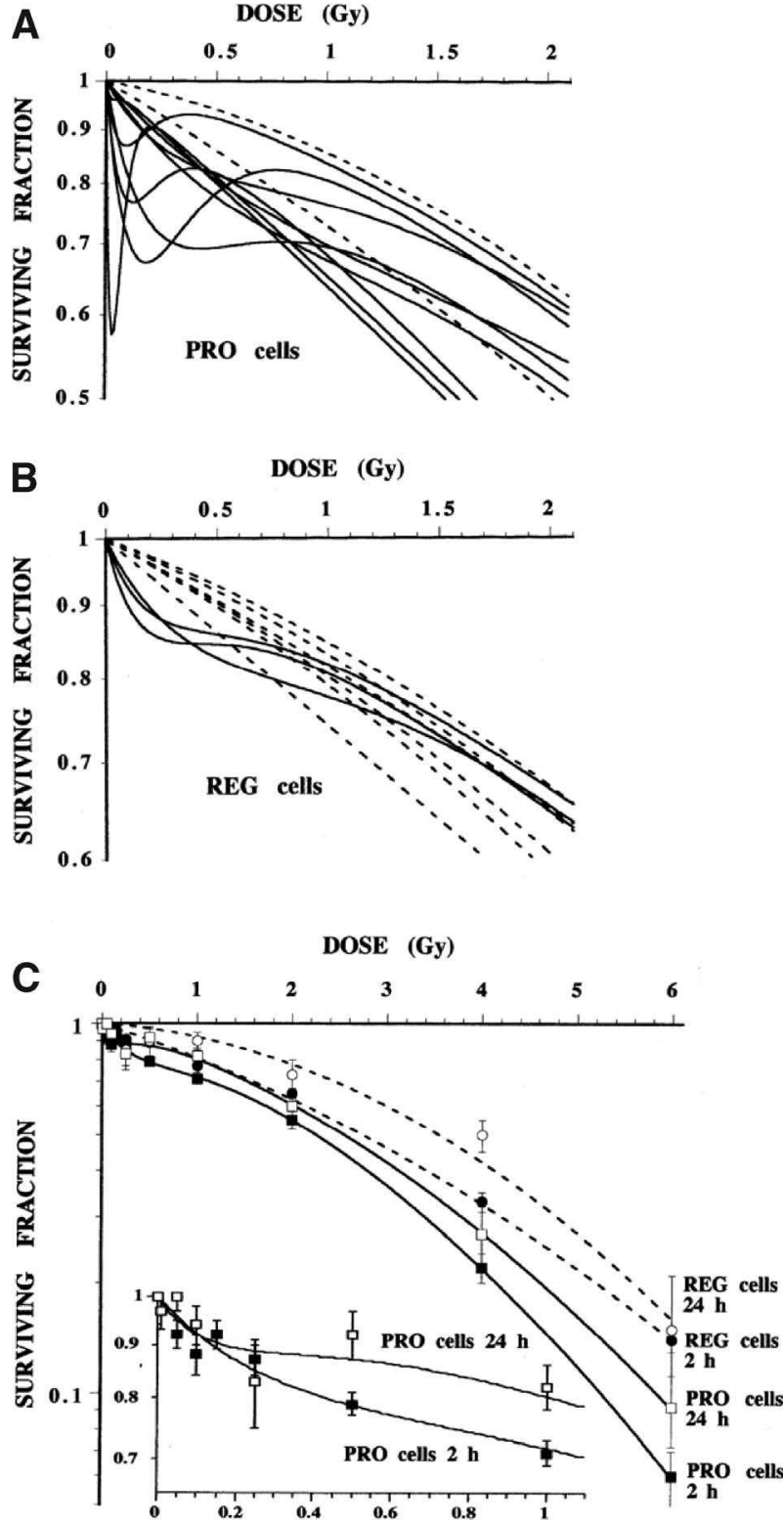

Figure 1. Survival curves of PRO/REG cells. Experiments were performed with cells cultured for no more than five passages. PRO cells (A) and REG cells (B) were irradiated $2 \mathrm{~h}$ after plating. Eleven and nine independent experiments were performed for PRO cells and REG cells, respectively. Only data fits to the most relevant model were represented for each experiment (LQ: dashed line; IR: continuous line). (C) Survival curves of PRO/REG cells irradiated $2 \mathrm{~h}$ and $24 \mathrm{~h}$ after plating. Each data plot represents the mean \pm SEM of 11 and 9 independent experiments for PRO and REG cells irradiated $2 \mathrm{~h}$ after plating, respectively and the mean \pm SEM of three and two independent experiments for PRO and REG cells irradiated $24 \mathrm{~h}$ after plating, respectively. Data fits to the most relevant model were represented for each cell line (LQ: dashed line; IR: continuous line). Insert shows a zoom of survival curves at doses below $1 \mathrm{~Gy}$.

We examined thereafter whether the percentage of $\mathrm{G}_{2} / \mathrm{M}$ cells evaluated before irradiation (i.e., $2 \mathrm{~h}$ or $24 \mathrm{~h}$ after plating) impacts upon the HRS response. Unirradiated PRO subline showed significantly less cells in $\mathrm{G}_{2} / \mathrm{M} 2 \mathrm{~h}$ after plating and significantly more cells in $\mathrm{G}_{2} / \mathrm{M} 24 \mathrm{~h}$ after plating than REG subline. Furthermore, since: (i) Unirradiated PRO subline showed significantly more cells in $\mathrm{G}_{2} / \mathrm{M} 24 \mathrm{~h}$ after plating than $2 \mathrm{~h}$ after plating (Figure $2 \mathrm{~A}$, left panel); (ii) PRO cells showed similar HRS response $2 \mathrm{~h}$ and $24 \mathrm{~h}$ after plating; and (iii) no significant HRS response was observed in REG cells whatever the time after plating (Figure 1C), our data suggest that the percentage of $\mathrm{G}_{2} / \mathrm{M}$ cells before irradiation cannot explain the difference in HRS response between PRO and REG sublines.

Cell cycle distributions were also examined in cells irradiated $24 \mathrm{~h}$ after plating at $0.1 \mathrm{~Gy}$ and $6 \mathrm{~Gy}$. A low-dose of $0.1 \mathrm{~Gy}$ was chosen to evaluate specifically the HRS and not the IRR response since the dose inducing the transition from HRS to IRR $\left(\mathrm{d}_{\mathrm{c}}\right)$ was $0.19 \pm 0.08 \mathrm{~Gy}$ for PRO cells irradiated $24 \mathrm{~h}$ after plating (Table I). A high-dose of $6 \mathrm{~Gy}$ that provided the largest survival difference between PRO and REG cells was chosen to compare data obtained after irradiation at $0.1 \mathrm{~Gy}$. Fifteen min, 1,6 and $24 \mathrm{~h}$ after irradiation at $0.1 \mathrm{~Gy}$, cell cycle distributions in PRO and REG cells remained unchanged compared to those observed in unirradiated cells, suggesting that a dose of $0.1 \mathrm{~Gy}$ is not sufficient to trigger significant cell cycle change whatever the subline (data not shown). By contrast, $24 \mathrm{~h}$ after irradiation at $6 \mathrm{~Gy}$, the $\mathrm{S}$ fraction significantly decreased in both sublines whereas the $G_{2} / M$ fraction significantly increased in PRO cells only when compared to unirradiated cells (Figure 2A, right panel).

DAPI staining and immunofluorescence performed with antibodies against phosphorylated H3 histone forms characterizing mitoses were also applied during immunofluorescence experiments in parallel to cytometry analysis. Mitotic cells represented less than $5 \%$ of cells and this feature remained unchanged after irradiation at 0.1 Gy (Figure 2B), consolidating therefore the cytometry data described above (Figure 2A). Hence, altogether, these findings suggest that the relative fraction of $\mathrm{G}_{2} / \mathrm{M}$ cells alone cannot explain the HRS response observed in PRO/ REG sublines.

\section{Cell death}

Clonogenic death is the final result of different radiation-activated death pathways such as apoptosis, mitotic death or senescence. We asked whether particular cell death pathway may explain the HRS response observed in PRO cells. By examining DAPI-stained cells with immunofluorescence, no apoptotic body was observed either between $15 \mathrm{~min}$ and $48 \mathrm{~h}$ after irradiation at $0.1 \mathrm{~Gy}$ or $24 \mathrm{~h}$ after irradiation at $6 \mathrm{~Gy}$ in PRO and REG cells (data not shown). Apoptosis can be mediated by p53-dependent and -independent pathways. However, since 

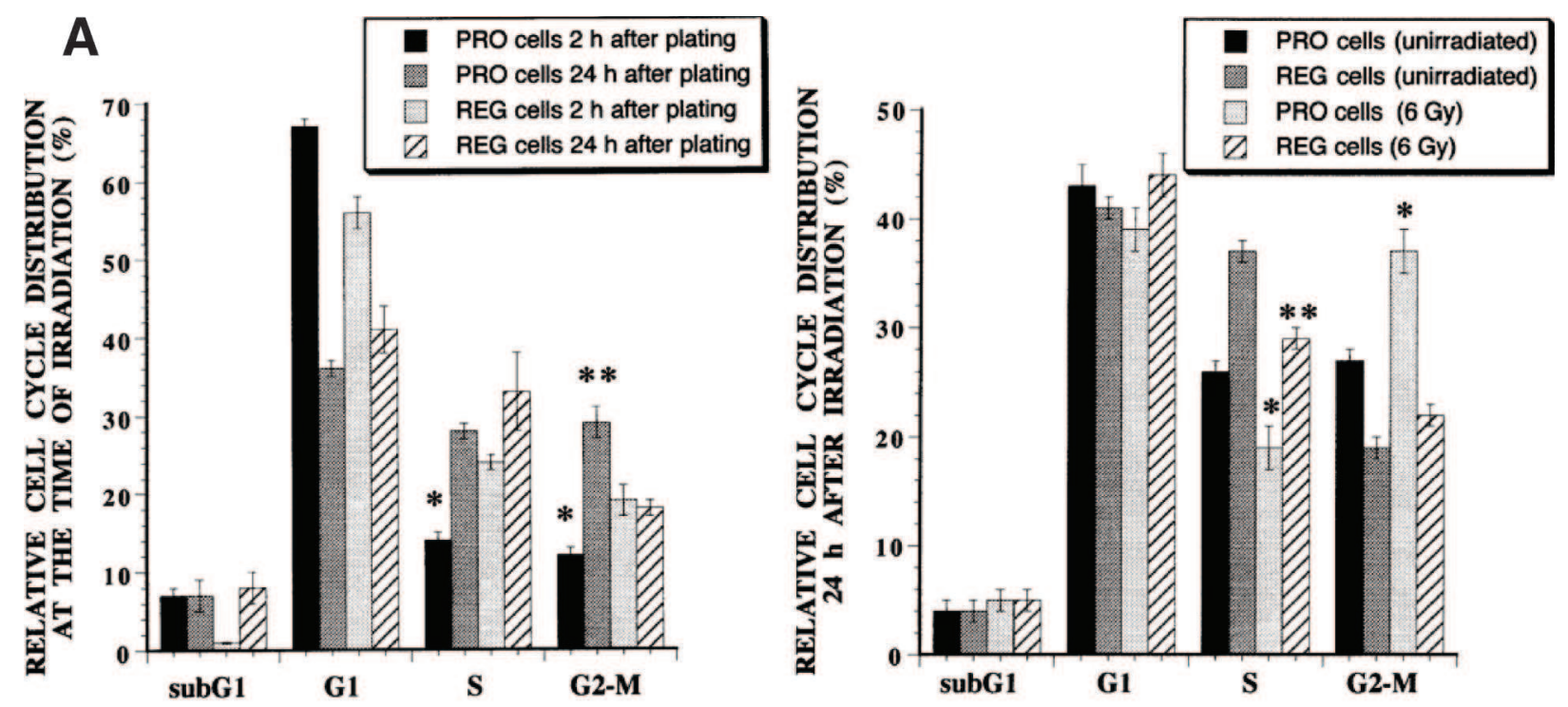

B
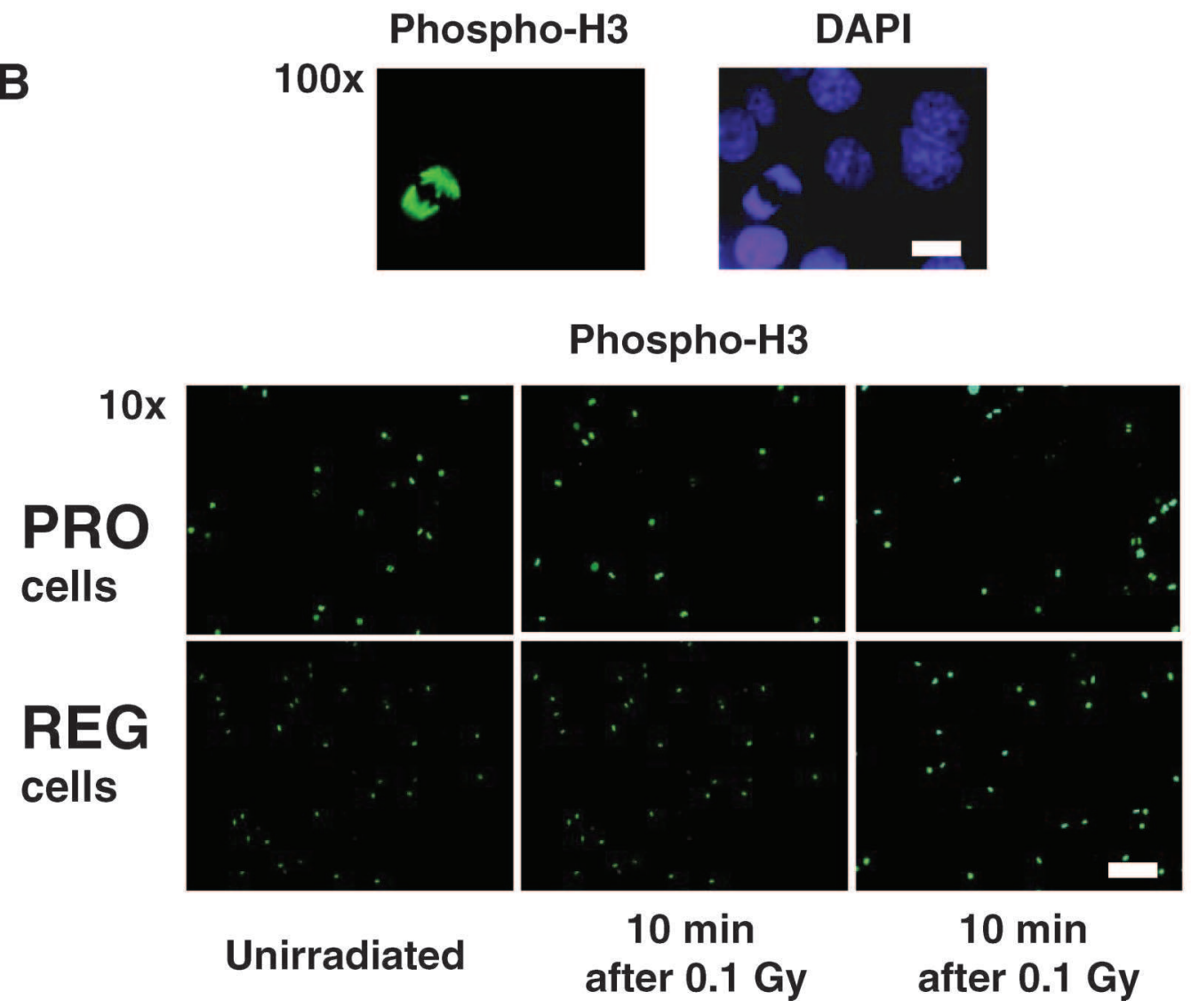

Figure 2. Cell cycle distribution in PRO/REG cells. (A) Left panel. Relative cell cycle distribution in unirradiated PRO/REG cells before irradiation, i.e., $2 \mathrm{~h}$ or $24 \mathrm{~h}$ after plating. ${ }^{\star} p<0.05$ and ${ }^{\star \star} p<0.05$ for comparison of data between unirradiated PRO cells and unirradiated REG cells $2 \mathrm{~h}$ and $24 \mathrm{~h}$ after plating, respectively and $\star^{\star} p<0.05$ for comparison between unirradiated PRO cells $2 \mathrm{~h}$ after plating to unirradiated PRO cells $24 \mathrm{~h}$ after plating using $t$-test. Right panel. Relative cell cycle distribution in PRO/REG cells $24 \mathrm{~h}$ after irradiation at 6 Gy. ${ }^{\star} p<0.05$ and ${ }^{\star \star} p<0.05$ for comparison of data between irradiated PRO and REG cells to unirradiated PRO and REG cells, respectively using $t$-test. Each data corresponds to the mean \pm SEM of four independent experiments. (B) Immunofluorescence data obtained with antibodies against phosphorylated histone H3 in PRO cells and REG cells. Upper panel shows a representative example of mitosis stained in fluorescein (green) and clearly identifiable in DAPI. This picture was obtained with the $100 \times$ microscope objective (the white bar represents $5 \mu \mathrm{m}$ ). Lower panel shows representative pictures with green-stained mitoses $10 \mathrm{~min}$ and $24 \mathrm{~h}$ after irradiation at $0.1 \mathrm{~Gy}$ in PRO/REG cells as observed in $10 \times$ microscope objective (the white bar represents $0.05 \mu \mathrm{m}$ ). 
p53-dependent apoptosis has been evoked to explain the HRS phenomenon (Enns et al. 2004), the occurrence of phosphorylated forms of p53 (pP53) was investigated by using specific immunofluorescence after irradiation at $0.1 \mathrm{~Gy}$ and $6 \mathrm{~Gy}$. Whereas pP53 appeared essentially cytoplasmic in both unirradiated PRO and REG cells, it was nuclear in rodent control cells. Four hours after irradiation at $0.1 \mathrm{~Gy}, \mathrm{pP} 53$ localization did not change in PRO and REG cells (Figure 3A). Similar conclusions were reached $24 \mathrm{~h}$ after irradiation at 6 Gy (data not shown). These data suggest a functional impairment of $\mathrm{p} 53$ in both unirradiated and irradiated $\mathrm{PRO} / \mathrm{REG}$ cells, consistent with absence of p53-dependent apoptosis. At this stage, it must be stressed that these results do not necessarily mean that the p53 protein is mutated in both sublines or that p53 mutations are similar. These results only provide information about the functionality of the ATMdependent phosphorylation of $\mathrm{p} 53$ that impacts upon cell cycle control and p53-dependent apoptosis.

Mitotic death is characterized by micronuclei formation. No cell with micronuclei was observed in unirradiated cultures. Forty-eight hours after irradiation at $0.1 \mathrm{~Gy}$, the percentage of cells showing one micronucleus was $37+5 \%$ and $2+0.3 \%$ (mean \pm SEM, $n=3$ ) in PRO and REG cells, respectively (Figure 3B). Such numbers are much higher than those previously obtained by Slonina et al. (2007) in irradiated primary human fibroblasts with a mean of $1.7 \%$ and a range of $0.3-3.8 \%$. However, it is noteworthy that capacity of proliferation, distribution in cell cycle, cell type and origin are deeply different (human fibroblasts versus rodent tumour cells), which may explain, at least in part, such a difference. Corresponding surviving fraction for PRO and REG cells irradiated $24 \mathrm{~h}$ after plating with $0.1 \mathrm{~Gy} \mathrm{X}$-rays were $0.85 \pm 0.04$ (mean \pm SEM, $n=6$ ) and $1.1 \pm 0.07$ (mean \pm SEM, $n=6$ ), respectively. Data support that mitotic death, more likely than p53dependent apoptosis, reflects HRS response in PRO cells. Since micronuclei result from propagation of unrepaired DNA breaks throughout cell cycle, DNA breaks in PRO/REG cells have been investigated.

\section{DNA SSB induction and repair}

From the analysis of 45 comets, the mean and the SEM of the tail moments in unirradiated PRO and REG cells were $66 \pm 10$ and $86 \pm 14$, respectively.

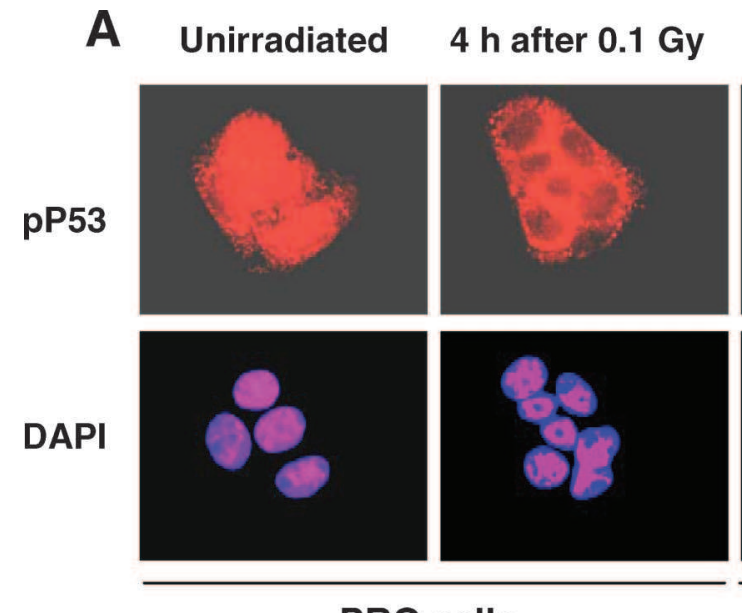

PRO cells

B

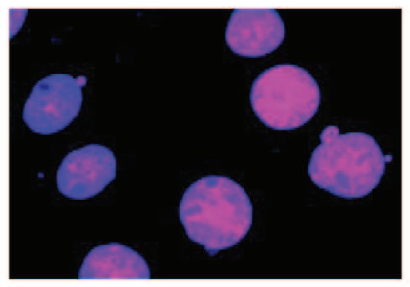

PRO cells
Unirradiated $\quad 4 \mathrm{~h}$ after $0.1 \mathrm{~Gy}$
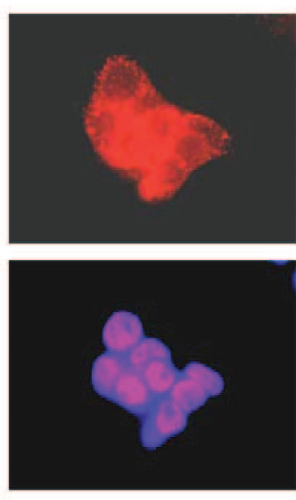

REG cells
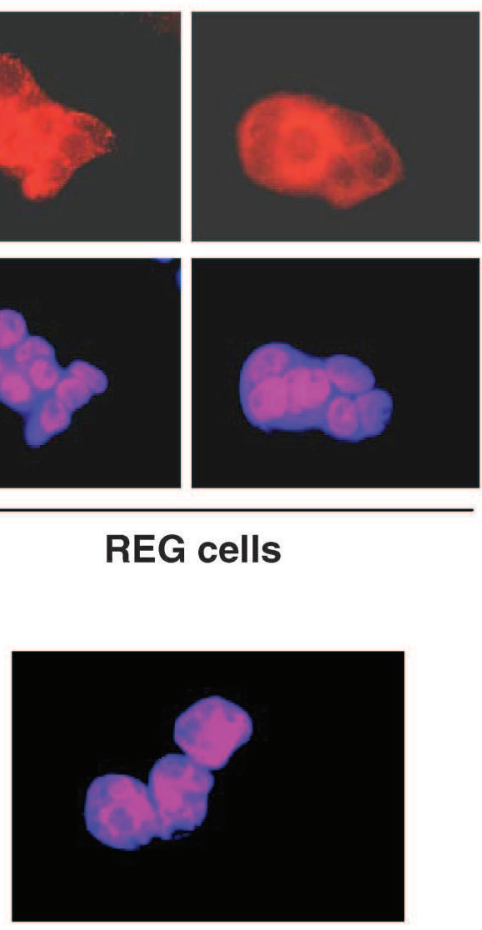

REG cells

\section{$4 \mathrm{~h}$ after 2 Gy}

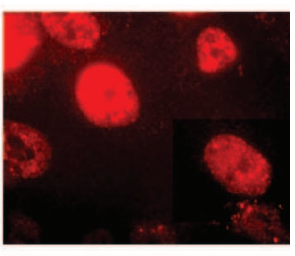

CHO cells

Figure 3. The p53-dependent apoptosis and the mitotic death in PRO/REG cells. (A) Anti-pP53 immunofluorescence performed in PRO and REG cells. Cells were either unirradiated (controls) or irradiated at $0.1 \mathrm{~Gy}$ followed by $4 \mathrm{~h}$ for repair. Chinese Hamster Ovary (CHO) cells were used as positive controls. (B) Micronuclei of PRO cells observed $48 \mathrm{~h}$ after irradiation at 0.1 Gy. No significant number of micronuclei was observed in REG subline whether in unirradiated cells or in irradiated cells $48 \mathrm{~h}$ after irradiation at $0.1 \mathrm{~Gy}$. 
These data suggest that the yield of spontaneous DNA SSB does not discriminate the PRO/REG sublines. Normalized tail moment (NTM) was chosen as an endpoint for describing the radiationinduced initial (i.e., assessed immediately after irradiation) and residual DNA SSB. The higher the dose, the higher the yield of initial DNA SSB (Figure 4A). However, such linear relationship did
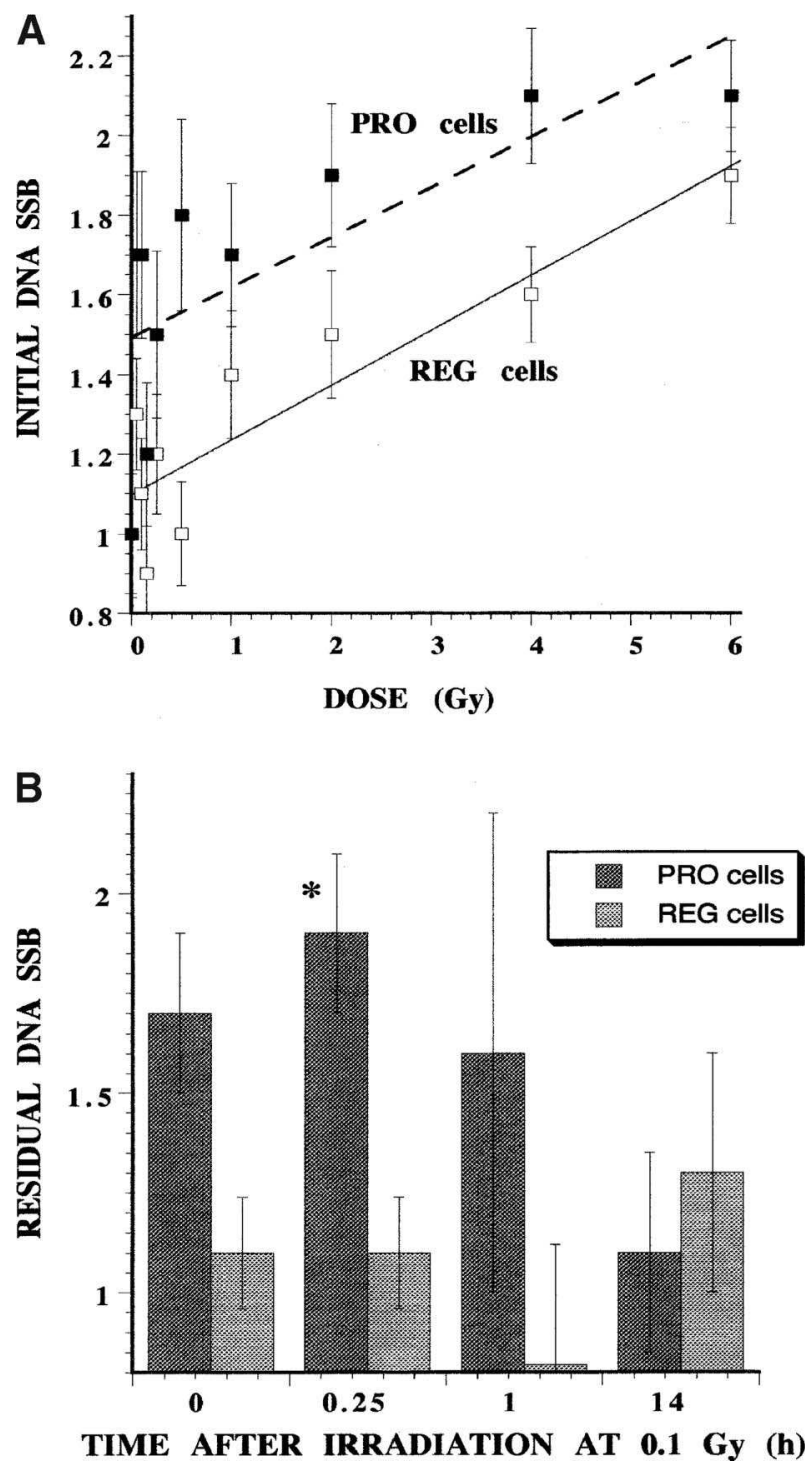

Figure 4. Initial and residual DNA SSB. (A) Initial DNA SSB. The number of DNA SSB assessed immediately after irradiation in PRO/REG cells was expressed as normalized tail moment (NTM). Each data representing the mean \pm SEM of three independent experiments was plotted against the corresponding radiation dose. NTM was found to be linearly linked to the dose for PRO/REG sublines $\left(\mathrm{R}^{2}=0.81, p<0.001\right.$ and $\mathrm{R}^{2}=0.52, p<0.05$, respectively). (B) Residual DNA SSB. The number of DNA SSB assessed at the indicated times after irradiation at $0.1 \mathrm{~Gy}$ in PRO/REG cells was expressed as NTM. Each data represents the mean \pm SEM of three independent experiments. Asterisk corresponds to a significant difference $(p<0.05)$ between PRO and REG cells by using the $t$-test. not display significant difference between PRO and REG cells. Indeed, although the yield of DNA SSB assessed immediately after irradiation at 0.1 and 6 Gy in PRO cells was significantly higher than that obtained in unirradiated cells, this endpoint was not significantly different in PRO and REG cells (data not shown), suggesting that initial DNA SSB cannot explain the difference observed in HRS response between PRO and REG cells.

During comet experiments, the presence of some cells highly damaged cells (HDC) may be noticed (Olive et al. 1993). In our conditions, a substantial fraction of HDC was observed in REG cells but not in PRO cells before irradiation with a median of $7 \%$ and $0 \%$ and ranges of $(0-33 \%)$ and $(0-0 \%)$, respectively. HDC were observed in PRO and REG cells immediately after irradiation but not between $15 \mathrm{~min}$ and $24 \mathrm{~h}$ post-irradiation (data not shown). When HDC were omitted from NTM data, the yield of initial DNA SSB as function of dose was similar in both sublines (data not shown). The biological significance of HDC is not clear. HDC may reflect transient but significant disturbances in chromatin since comet assay is prominently influenced by chromatin organization (e.g., Kumar et al. 2002). It was also suggested that HDC may be apoptotic cells occurring rapidly after irradiation (e.g., Olive et al. 1993). However, no apoptotic body was observed between $15 \mathrm{~min}$ and $48 \mathrm{~h}$ after irradiation at 0.1 and $6 \mathrm{~Gy}$ in both sublines. Lastly, the number of HDC was neither correlated with radiation doses nor with surviving fractions in both sublines (data not shown). Altogether, these data suggest therefore that, like initial DNA SSB, HDC cannot explain the difference in HRS response between PRO and REG cells.

With regard to residual DNA SSB, NTM assessed 15 min after irradiation at 0.1 Gy was significantly higher in PRO cells than in REG cells while no significant difference between irradiated and unirradiated PRO/REG sublines data was observed for longer times after irradiation at $0.1 \mathrm{~Gy}$ (Figure 4B). Furthermore, PRO cells showed three-fold more DNA SSB 15 min after irradiation at 6 Gy than REG cells (data not shown), suggesting a production of additional DNA SSB after irradiation. Altogether, these data showed that after irradiation at 0.1 and 6 Gy, there is no significant difference in initial and residual DNA SSB between both sublines, to the notable exception of a DNA SSB burst observed 15 min after irradiation in PRO cells only.

Induction and repair of DNA DSB processed by the NHEF pathway

DNA DSB induction and repair were examined by using immunofluorescence with specific antibodies 
against $\mathrm{H} 2 \mathrm{AX}$ phosphorylation ( $\mathrm{pH} 2 \mathrm{AX}$ ), an early NHEJ event (Rothkamm \& Löbrich 2003). The number of spontaneous pH2AX foci was not significantly different in both sublines. Ten min and $1 \mathrm{~h}$ after irradiation at $0.1 \mathrm{~Gy}$, the number of pH2AX foci per cell was significantly higher in PRO cells than in REG cells. Furthermore, $24 \mathrm{~h}$ after irradiation at $0.1 \mathrm{~Gy}$, the number of $\mathrm{pH} 2 \mathrm{AX}$ foci per cell was significantly higher in irradiated PRO cells than that obtained in unirradiated PRO cells (Figure 5A). Such a difference in DSB repair rate was confirmed $24 \mathrm{~h}$ after irradiation at $6 \mathrm{~Gy}$ (data not shown), suggesting an impairment of the NHEJ process in PRO cells but not in REG cells.

Since ATM and DNA-PK kinases are responsible for the H2AX phosphorylation, the radiationinduced kinase activity was evaluated by using antibodies against autophosphorylated ATM and DNA-PK forms that re-localize as nuclear foci (pATM and pDNA-PK, respectively). The number of pDNA-PK and pATM foci in PRO cells was similar to that observed in REG cells after irradiation at 0.1 Gy but higher to that obtained in REG cells after irradiation at $0.2 \mathrm{~Gy}$ (Figure 5B). Hence, these findings suggest that the HRS response observed in PRO cells after irradiation at 0.1 Gy cannot be explained by impaired ATM and/or DNA-PK kinase activities required for the DNA DSB recognition during the NHEJ process.

The MRE11 protein, associated with hyperrecombination and genomic instability (Joubert \& Foray 2006; Joubert et al. 2008), was found essentially cytoplasmic in both sublines, while a rodent control showed a normal formation of radiation-induced MRE11 nuclear foci, suggesting that the HRS response in PRO cells is MRE11independent (data not shown).

\section{Induction and repair of DNA DSB processed by RAD51-dependent recombination pathway}

While NHEJ is the major DNA DSB repair pathway acting in $G_{1}$ cells, DNA DSB in $S-G_{2} / M$ cells are more likely repaired by the RAD51dependent recombination. Since radiation-induced RAD51 foci are generally tiny and numerous, the percentage of cells showing RAD51 foci rather than their yield per cell was chosen as endpoint. Unlike with $\mathrm{pH} 2 \mathrm{AX}$ assay, the percentage of cells showing spontaneous RAD51 foci was five-fold higher in PRO cells than in REG cells (data not shown). A similar conclusion was reached $4 \mathrm{~h}$ after irradiation at 0.1 Gy. At such dose, RAD51 remained cytoplasmic in REG cells, suggesting that this protein was activated after 0.1 Gy in PRO cells only (Figure 6A). By contrast, after irradiation at 6 Gy, $90 \%$ of REG cells and $30 \%$ of PRO cells elicited RAD51 foci (Figure 6A). Since RAD51dependent repair is active in $S-G_{2} / M$ cells only, the relationship between RAD51 data and the corresponding cell cycle distributions was investigated. Before irradiation, the percentages of $S-G_{2} / M$ cells in both sublines were similar before irradiation $(57 \pm 2 \%$ and $51 \pm 6 \%$ (mean \pm SEM, $n=4)$ in PRO and REG cells, respectively) (Figure 2A). After irradiation at 0.1 and $6 \mathrm{~Gy}$, a significant linear relationship was detected between the percentage of cells showing RAD51 foci and the percentage of S$\mathrm{G}_{2} / \mathrm{M}$ cells in PRO cells but not in REG cells (Figure 6B), suggesting that unrepaired DNA DSB processed by the RAD51-dependent repair pathway may propagate through the cell cycle in PRO cells but not in REG cells.

\section{Discussion}

PRO/REG sublines: $A$ useful model to study HRS response

PRO/REG sublines have been deliberately chosen to test whether HRS response is more marked in tumorigenic cells with high metastatic potential than in non-tumorigenic cells with no metastatic potential. PRO/REG sublines were obtained from the same parental rat colon tumour, which made possible molecular and cellular investigations on HRS response in the frame of tumour heterogeneity. Here, our data indicate that PRO cells show more HRS response than REG cells, consistently with literature showing that tumorigenic cells are generally more radiosensitive than non-tumorigenic cells (e.g., Barnetson et al. 1999). Our observations provide evidence that neither cell cycle distribution alone (both sublines elicited similar $\mathrm{S}-\mathrm{G}_{2} / \mathrm{M}$ fraction before irradiation) nor p53-dependent apoptosis (not relevant here) nor HDC (REG cells spontaneously showed more HDC than PRO cells) may explain the fact that PRO cells show higher HRS response than REG cells.

Impact of the major DNA repair pathways upon HRS response

Induction and repair of DNA SSB and DSB were investigated by using alkaline comet and $\mathrm{pH} 2 \mathrm{AX}$, pATM, pDNA-PK, MRE11 and RAD51 immunofluorescence assays. Alkaline comet assay allowing the assessment of initial and residual DNA SSB has been already applied to low-dose (6 mGy) (Malyapa et al. 1998) or very-low chronic radiation dose-rate $\left(20 \mu \mathrm{Sv} \cdot \mathrm{h}^{-1}\right)$ (Meehan et al. 2004). The H2AX assay that allows the detection of DNA DSB has already proved its efficiency at very low-dose like 1.2 mGy (Rothkamm \& Löbrich 2003). 
A
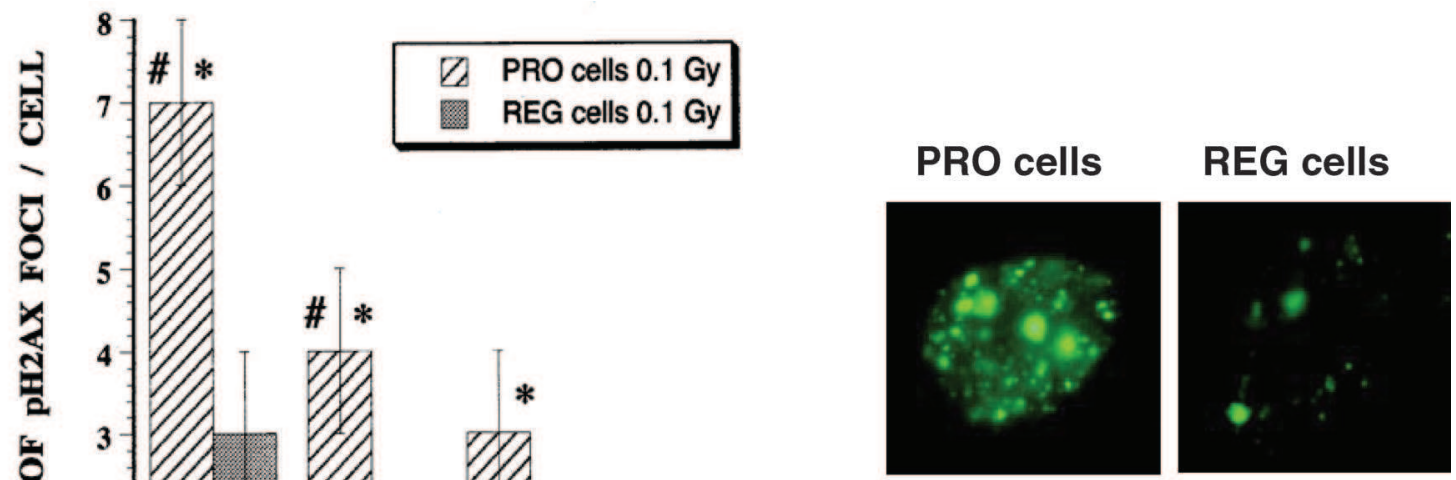

pH2AX 10 min after $0.1 \mathrm{~Gy}$

\section{B} TIME AFTER IRRADIATION (h)

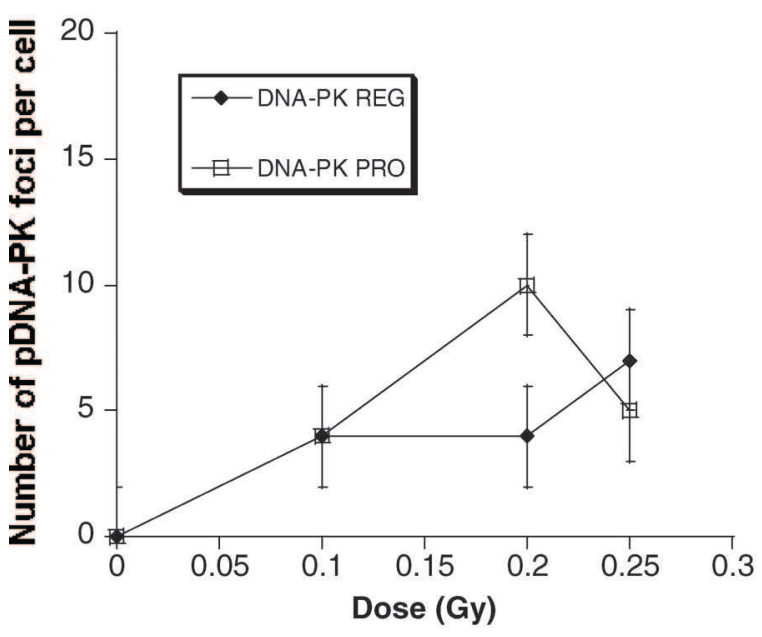

$0.1 \mathrm{~Gy}$

PRO

cells

REG

cells

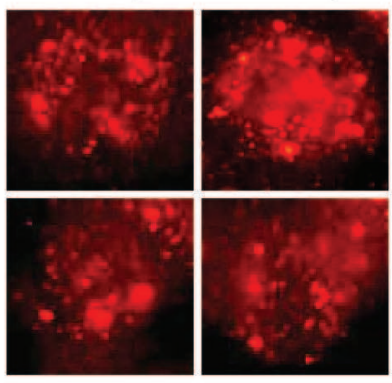

PDNA-PK 10 min post-irradiation

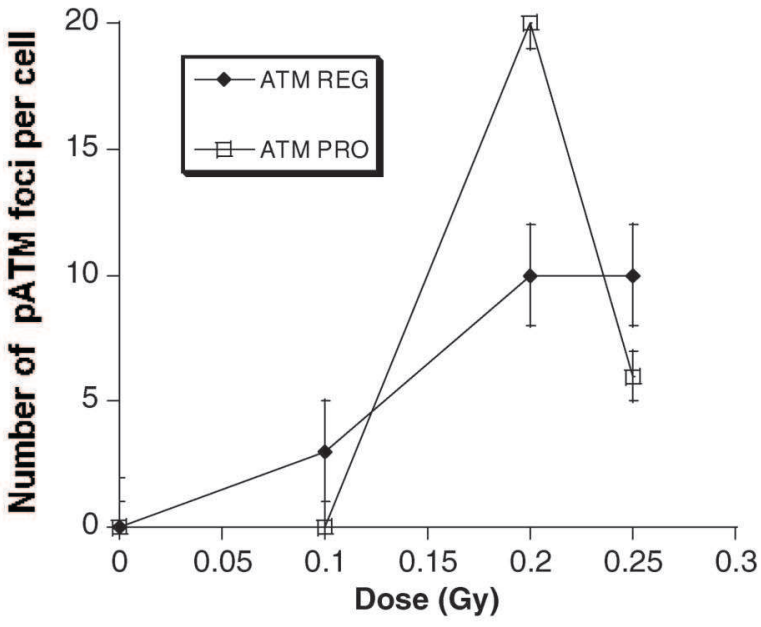

$0.1 \mathrm{~Gy}$

0.2 Gy

PRO

cells
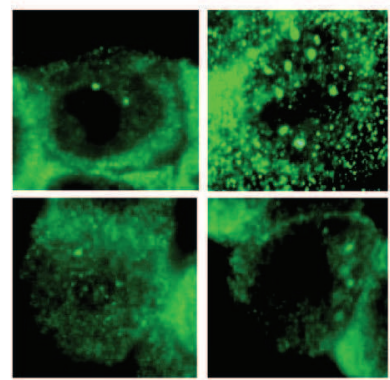

PATM 10 min post-irradiation

Figure 5. Initial and residual DNA DSB processed by the NHEJ repair pathway. (A) Left panel. DSB induction and repair after irradiation at $0.1 \mathrm{~Gy}$. The number of pH2AX foci per cell was plotted against the post-irradiation times. Each data represents the mean \pm SEM of two independent experiments. ${ }^{\#} p<0.05$ and ${ }^{\star} p<0.05$ for comparison of data between irradiated PRO and REG cells and between irradiated PRO cells and unirradiated PRO cells, respectively using $t$-test. Right panel. Representative $\mathrm{pH} 2 \mathrm{AX}$ signals provided by PRO/REG cells 10 min after irradiation at 0.1 Gy. (B) The number of pDNA-PK (left panel) and pATM (right panel) foci per cell assessed 10 min after irradiation was plotted against the indicated radiation doses in PRO/REG sublines. Each data represents the mean \pm SEM of two independent experiments. Corresponding representative pictures of pATM and pDNA-PK are shown below. 

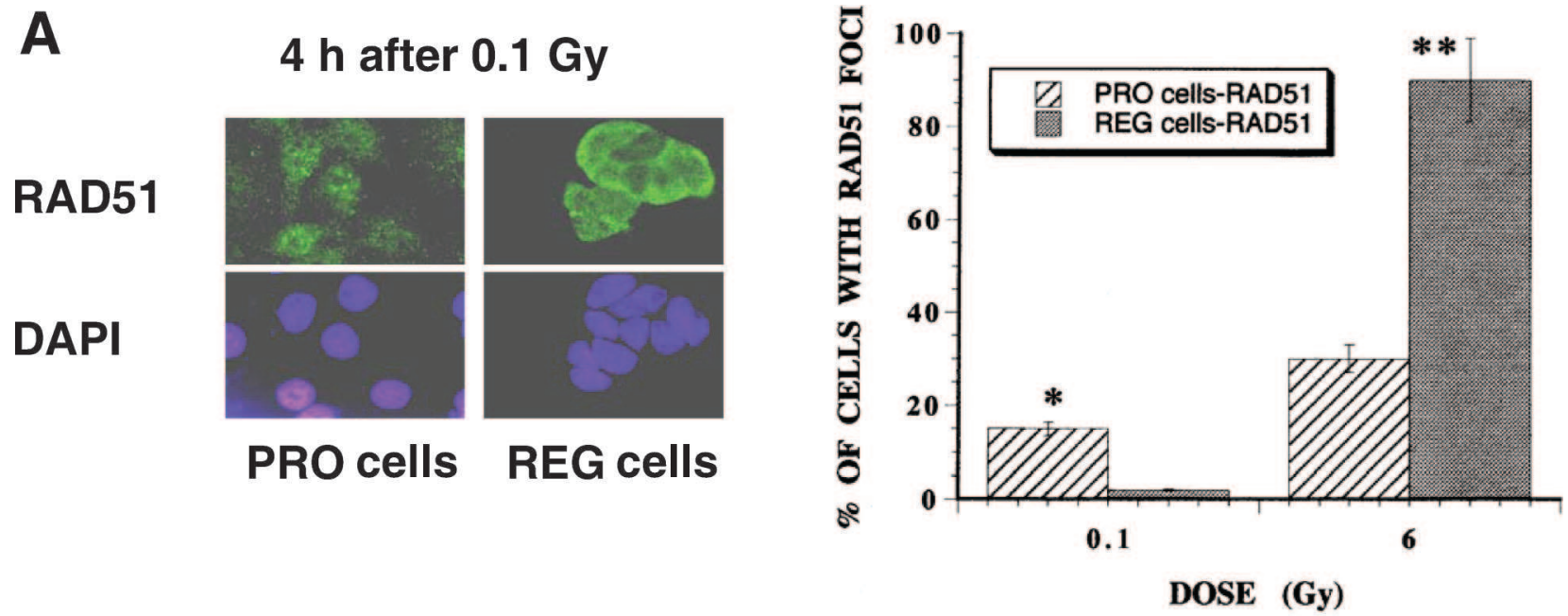

B

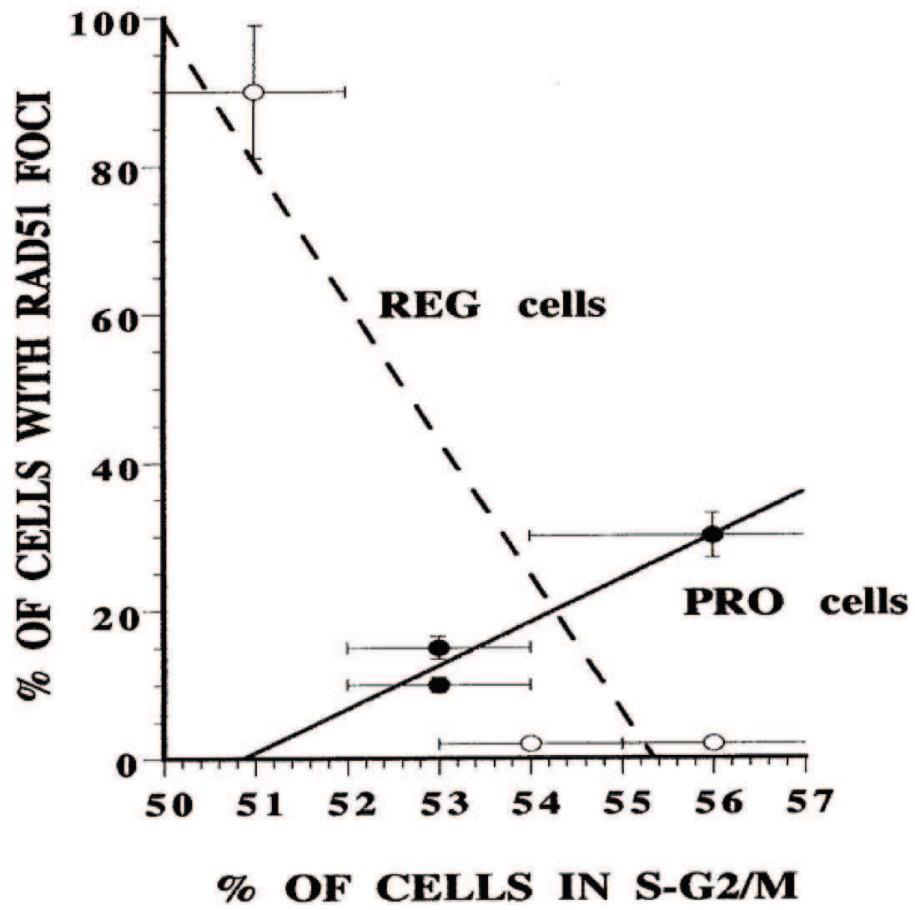

Figure 6. DNA DSB processed by the RAD51-dependent recombination repair pathway. (A) Left panel. Representative RAD51 signals obtained $4 \mathrm{~h}$ after irradiation at $0.1 \mathrm{~Gy}$. Right panel. Percentages of cells with RAD51 foci assessed $4 \mathrm{~h}$ after irradiation are shown at the indicated doses (0.1 and 6 Gy). Each data represents the mean \pm SEM of two independent experiments. ${ }^{\star} p<0.05$ and ${ }^{\star \star} p<0.05$ for comparison of data between PRO cells and REG cells irradiated at $0.1 \mathrm{~Gy}$ and 6 Gy, respectively using $t$-test. (B) The percentages of cells with RAD51 foci were plotted against the corresponding percentages of S- $\mathrm{G}_{2} / \mathrm{M}$ cells after irradiation at 0.1 and 6 Gy. Each data represents the mean \pm SEM of two independent experiments for RAD51 data and four independent experiments for cell cycle data. A significant linear correlation between RAD51 and cell cycle data was found for PRO cells (continuous line; $\mathrm{R}^{2}=0.94, p<0.05$ ) but not for REG cells (dashed line).

With regard to spontaneous DNA damage, PRO and REG sublines elicited similar yields of DNA SSB and DSB recognized by alkaline comet and pH2AX assays, respectively. Conversely, the RAD51 data revealed more spontaneous DNA damage in PRO than in REG cells, which cannot be explained by differences in the cell cycle distribution between both sublines. Hence, these findings support that such spontaneous DNA damage are processed in
PRO cells specifically by the RAD51-dependent pathway but not by the NHEJ one. The RAD51dependent recombination pathway is able to manage SSB and DSB, and unlike NHEJ, can produce DNA SSB intermediates during the DNA DSB repair process (Raderschall et al. 1999, Schlegel et al. 2006). Hence, we propose that $S-G_{2} / M$ PRO cells are characterized by a lack of control in the RAD51 endonuclease function through hyper-recombination 
(e.g., Schultz et al. 2003). Whether the DNA SSB burst observed $15 \mathrm{~min}$ after irradiation at 0.1 and 6 Gy in PRO cells is consistent with induction of DNA SSB during repair of DNA DSB needs further investigations. However, it raises the problem of the impact of the cell cycle distribution upon the evaluation of HRS response. Indeed, any impairment of RAD51-dependent repair should not be visible in quiescent cells. Interestingly, only two among forty human primary fibroblasts elicit HRS response (Slonina et al. 2007). This last observation might be explained by the propensity of fibroblasts to be essentially in $G_{1}$ phase. A direct consequence of a lack of control of RAD51-dependent repair would be also that PRO cells elicit higher chromatin fragility and genomic instability. Besides, the influence of chromatin fragility was already demonstrated in the radiosensitivity of some tumour cell lines (Chavaudra et al. 2004) and in ataxia telangiectasia or Xeroderma Pigmentosum fibroblasts (Puvion-Dutilleul 7 Sarasin 1989).

With regard to radiation-induced DNA damage, the data presented here suggest that the HRS response in PRO cells may not be explained by an impairment in DNA DSB recognition, in agreement with data from Wykes et al. (2006). Along with this normal DNA damage recognition, PRO and REG sublines elicited after irradiation similar initial DNA SSB yields but PRO cells showed significantly more initial DNA DSB than REG cells, suggesting again higher chromatin fragility in PRO cells.

With regard to unrepaired DNA DSB, PRO cells displayed more impaired damage processed by the NHEJ pathway after irradiation at 0.1 and 6 Gy than REG cells. Such a conclusion is in agreement with the relative defect of DNA DSB repair in fibroblasts that show HRS response after irradiation at $1.2 \mathrm{mGy}$ (Rothkamm \& Löbrich 2003). Besides, after irradiation at $0.1 \mathrm{~Gy}$, PRO cells displayed more unrepaired DNA breaks processed by the RAD51 repair pathway than REG cells, consistently with a previous report showing that HRS response is associated with an increase of the number of RAD51 foci per cell after low-dose radiation (Short et al. 2005). Altogether, the analysis of the radiation-induced DNA damage after irradiation at 0.1 Gy suggests that more numerous and less repairable DNA lesions occur in PRO cells than in REG cells. Such phenomenon concern the two major DNA breaks repair pathways: NHEJ acting in $G_{1}$ and the RAD51-dependent recombination acting in $S-G_{2} / M$.

\section{Impact of the cell cycle distribution upon HRS response}

It was suggested that $G_{2}$ cells may dominate HRS response, which may be specific to damaged cells that fails to activate a transient $G_{2} / M$ checkpoint and enter into mitosis with unrepaired DNA breaks (Marples et al. 2004). Although the $\mathrm{G}_{2} / \mathrm{M}$ checkpoint was not the scope of this study, our observation that the cell cycle distribution in PRO cells after irradiation at $0.1 \mathrm{~Gy}$ is similar to that of unirradiated cells, may be consistent with a failure to induce $\mathrm{G}_{2} / \mathrm{M}$ arrest after irradiation at low doses. Such a conclusion is in agreement with previous reports (Marples et al. 2003, Krueger et al. 2007b), although we emphasized that the HRS response may not be dominated by the fraction of $\mathrm{G}_{2} / \mathrm{M}$ cells only. Experimental conditions may explain discrepancies in literature, e.g., irradiation was performed with cells in suspension that were plated after irradiation (Marples et al. 2003, Krueger et al. 2007b) whereas, in our study, irradiation was performed with adherent cells.

\section{Impact of the cell death pathway upon HRS response}

Such cascade of impaired events would likely result in micronuclei or apoptotic bodies. With PRO/REG cells, our data suggest that unrepaired DNA breaks induce mitotic death, but not p53-dependent apoptosis. This conclusion is not in agreement with the reports supporting that HRS response is associated with p53-dependent apoptosis in other tumour cell lines (Enns et al. 2004, Krueger et al. 2007a). Besides, whether HRS response is caused by unrepaired DNA breaks inducing apoptosis and/ or mitotic death still remains controversial and, again, likely depends upon: (i) The experimental conditions (Joiner et al. 2001, Chandna et al. 2002, Rothkamm \& Löbrich 2003) and notably whether cells were derived from exponential-phase or plateau-phase cultures (Krueger et al. 2007a); and (ii) the status of the genes and/or the functionality of their corresponding proteins involved in HRS, e.g., whether cells are p53-mutated or wild-typed (Enns et al. 2004, Krueger et al. 2007a), normal fibroblasts (Rothkamm \& Löbrich 2003) or oncogene-transformed or DNA repair-deficient fibroblasts (Wykes et al. 2006).

\section{Model for HRS response}

We propose that the HRS response in PRO subline is induced by both:

(1) An impairment of NHEJ repair in $\mathrm{G}_{1}$ cells. It is noteworthy that impaired NHEJ is responsible for intrinsic radiosensitivity whatever the dose. Since it has been recently demonstrated that the level of NHEJ impairment is quantitatively predictive of intrinsic radiosensitivity (Joubert \& Foray 2006; Joubert et al. 2008), we suggest that the level of NHEJ impairment may predict 
the slope of the initial part of the survival curve $\left(\alpha_{\mathrm{s}}\right)$ and therefore the HRS phenomenon.

(2) A lack of control of RAD51-dependent pathway in $S-G_{2} / M$ cells. However, since such a pathway is active in $S-G_{2} / M$ cells only, its impact upon HRS requires both sufficient fraction of $S-G_{2} /$ $\mathrm{M}$ cells at the time of irradiation and failure to arrest in cell cycle to allow propagation of unrepaired DNA damage in cell cycle. It is probable that such requirements are reached after irradiation at $0.1 \mathrm{~Gy}$ whereas irradiation at 6 Gy would limit such propagation by longer arrest in $\mathrm{G}_{2}$. Lastly, such an impairment would be responsible for the production of additional SSB, favoring the chromatin fragility and the genomic instability in PRO cells and interfering again into DNA repair and DNA damage propagation.

The cellular consequences of such repair and cell cycle deficiencies are cell death that may be either mitotic death or $\mathrm{p} 53$-dependent apoptosis depending on the genetic status of the irradiated cells. Alternatively, if there is no significant impairment in NHEJ and RAD51-dependent repair pathways or cell cycle arrest after irradiation, the HRS response is low or absent (Figure 7). Interestingly, such requirements for HRS response were previously evoked in the case of 19 tumour cell lines for high doses: The tumour cell lines showing the most severe radiosensitivity should elicit both DNA repair and chromatin defects. Any intermediate situation provides moderate radiosensitivity (Chavaudra et al. 2004). Further investigations are now needed to identify what kind of DNA damage would cause DNA repair deficiency and HRS response and whether other highly metastatic clones deriving from the same parental tumour cell line display similar or different HRS mechanisms.

\section{HRS response: Potential impact upon radiotherapy of micrometastases}

The HRS response was detected in many tumour cell lines and a few normal cell lines when irradiated at low-density (Joiner et al. 2001). Since tumour cells irradiated at high-density were protected from HRS response (Chandna et al. 2002), it is unlikely that high-density primary or secondary tumours show HRS response. An overview of radiobiological reports in which HRS response was not specifically investigated supports that inside a given tumour cell line, highly metastatic clones are more radiosensitive at high doses (i.e., higher than $0.5 \mathrm{~Gy}$ ) than poorly metastatic ones (Fu et al. 1976, Welch et al. 1983, Rao et al. 1991, Barnetson et al. 1999). Moreover, metastatic nodules to skin elicit marked HRS
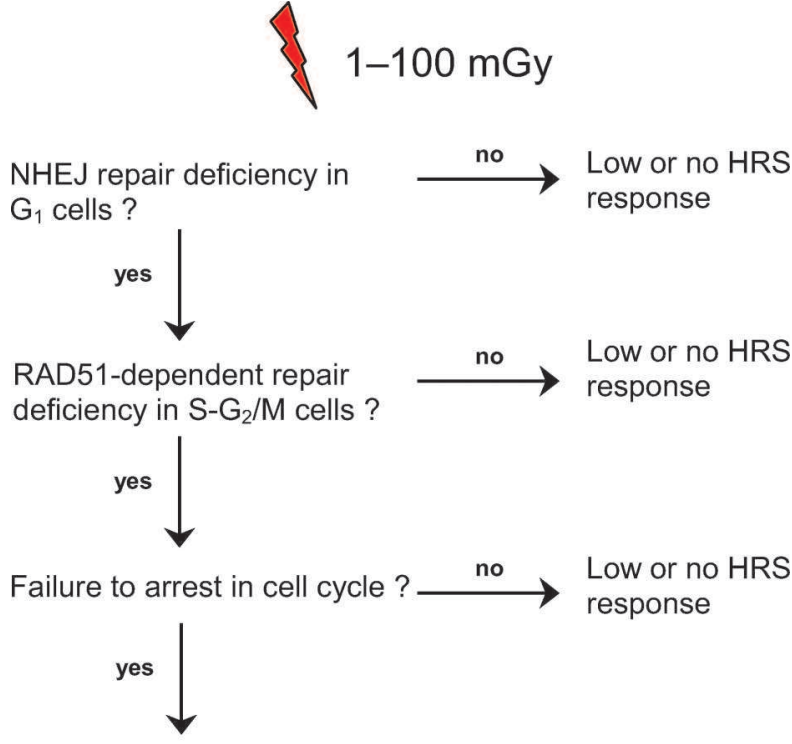

Propagation of unrepaired damage in cell cycle

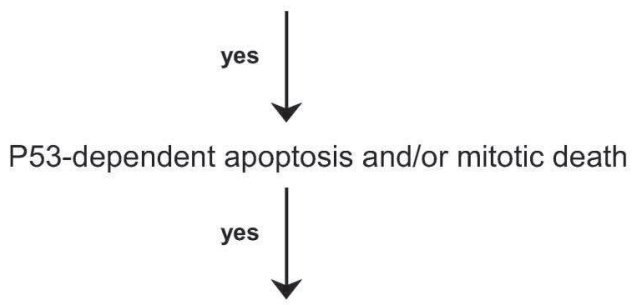

Marked HRS response

Figure 7. Model for the HRS phenomenon.

response in vivo. However, in this particular case, the mechanisms involved are still unclear since no radiosensitivity data from nodules was provided (Harney et al. 2004). We have previously shown that the more the clones isolated from a same parental human melanoma cell line are metastatic, the more they show marked HRS response (Thomas et al. 1997). To better illustrate this concept, we reexamined previous data from Thomas et al. (1997) that were fitted to the IR and 2-pop LQ models (Figure 8 ). Clone 4 with high metastatic potential showed HRS response while clone 1 with low metastatic potential did not. Variant 1 with intermediate metastatic potential displayed both HRS and IRR responses. However, these data were obtained from cells at early passages and no HRS response was observed at late passages (Thomas et al. 1997). Similar conclusions were also reached with PRO cells (data not shown). Our data suggest therefore that HRS response is both an inherent feature of micrometastases and a transient phenomenon, likely due to high genetic instability and heterogeneity of micrometastases (Klein et al. 2002).

HRS response may find applications in radiotherapy of micrometastases. Some early 


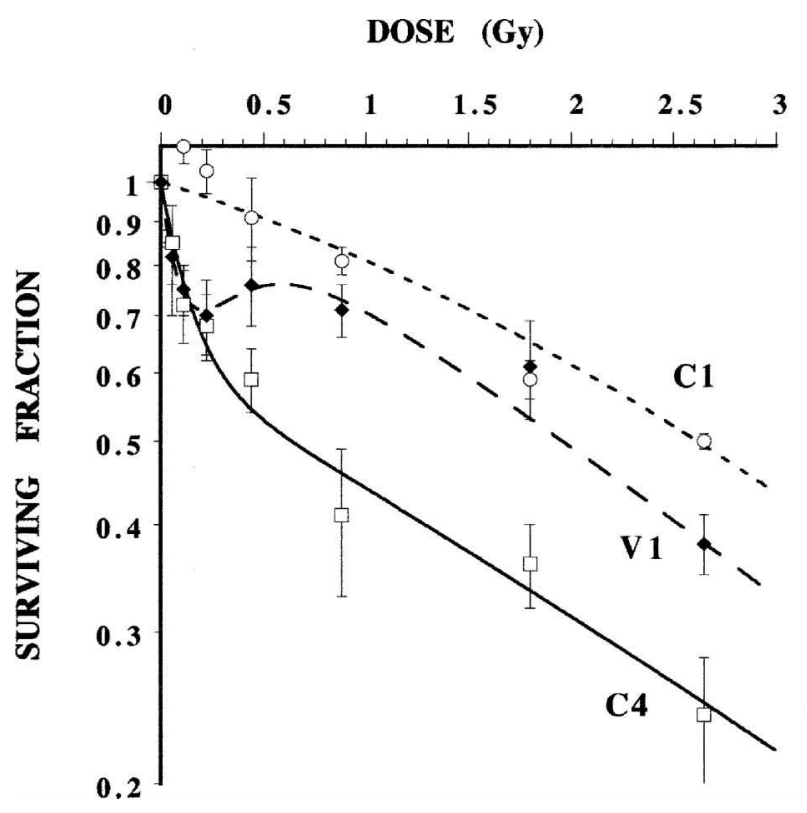

Figure 8. HRS response and metastatic potential. Survival curves of clone $\mathrm{C} 1$ with low metastatic potential, variant $\mathrm{V} 1$ with intermediate metastatic potential and clone $\mathrm{C} 4$ with high metastatic potential. C1, C4 and V1 are derived from the same parental human melanoma cell line M4Be. Raw data taken from Thomas et al. (1997) were fitted to models. Each data represents the mean \pm SEM of three independent experiments. $\mathrm{C} 1$ survival data are well fitted by the LQ model while C4 and V1 data are well fitted by the 2-pop LQ and IR models, respectively.

disseminated and probably unvascularised cells may escape chemotherapy after excision of $\mathrm{M}_{0}$ primary tumour. Evidence was provided that low-dose total body irradiation (TBI) at doses lower than $20 \mathrm{cGy}$ reduces metastatic potential in rodents by immune system stimulation (Hosoi \& Sakamoto 1993, Hashimoto et al. 1999, Liu 2003)). Since highly metastatic cells may display HRS response, we proposed to apply eventually a low-dose TBI after excision of $\mathrm{M}_{0}$ primitive tumours to prevent micrometastases development (Thomas et al. 2001). To test such hypothesis, the smallest dose producing HRS response without increasing cancer must be found. Very low doses such as $1.2 \mathrm{mGy}$ may both induce HRS response (Rothkamm \& Löbrich 2003) and reduce the risk of cancer transformation compared to unirradiated cells (Azzam et al. 1996, Redpath et al. 2003, Portless et al. 2007). In addition, irradiation at $30 \mathrm{cGy} \mathrm{X}$-rays applied to mice, whether externally or in utero, did not show significant increase of cancer (Di Majo et al. 2003). Epidemiological data suggest that the lowest dose of X-or $\gamma$ radiation showing increased cancer risk in humans may be situated between 10 and 50 mGy (Brenner et al. 2003). Thus, even if literature data consolidate the relevance of our hypothesis, the application of preventive TBI treatments at very low dose (i.e., lower than $10 \mathrm{mGy}$ ) raises the problem of the threshold dose in cancer incidence and requires further and careful investigations. Studies using the $\mathrm{PRO} / \mathrm{REG}$ syngeneic model are in progress to secure the applicability of preventive very low-doses TBI in the radiotherapy of micrometastases.

\section{Acknowledgements}

We thank the reviewers for their helpful comments. We are grateful to J-F. Chatal (Inserm U601, Nantes) and A. Courdi (CAC, Nice) for support and stimulating discussions, Guy Brunet's team (CRG, Nantes), F. Estève, (Inserm U836, Grenoble), A. Joubert (IRSN, Cadarache) and M. Viau (ESRF, Grenoble) for their technical help. This work was supported by APRAT, ARC, EDF and ETOILE Project (Région Rhône-Alpes and Lyon University).

Declaration of interest: The authors report no conflicts of interest. The authors alone are responsible for the content and writing of the paper.

\section{References}

Alapetite C, Wachter T, Sage E, Moustacchi E. 1996. Use of the alkaline comet assay to detect DNA repair deficiencies in human fibroblasts exposed to UVC, UVB, UVA and $\gamma$ rays. International Journal of Radiation Biology 69:359-369.

Azzam EI, de Toledo SM, Raaphorst GP, Mitchel RE. 1996. Lowdose ionizing radiation decreases the frequency of neoplastic transformation to a level below the spontaneous rate in $\mathrm{C} 3 \mathrm{H}$ $10 T_{1 / 2}$ cells. Radiation Research 146:369-373.

Barnetson AR, Banasiak D, Fischer RJ, Mameghan H, Ribeiro JC, Brown K, Brown JL, O'Mara SM, Russell PJ. 1999. Heterogeneity of in vitro radiosensitivity in human bladder cancer cells. Radiation Oncology Investigations 7:66-76.

Brenner DJ, Doll R, Goodhead DT, Hall EJ, Land CE, Little JB, Lubin JH, Preston DL, Preston RJ, Puskin JS, Ron E, Sachs RK, Samet JM, Setlow RB, Zaider M. 2003. Cancer risks attributable to low doses of ionizing radiation: Assessing what we really know. Proceedings of the National Academy of Sciences, USA 100:13761-13766.

Chandna S, Dwarakanath BS, Khaitan D, Mathew TL, Jain V. 2002. Low-dose radiation hypersensitivity in human tumor cell lines: effects of cell-cell contact and nutritional deprivation. Radiation Research 157:516-525.

Chavaudra N, Bourhis J, Foray N. 2004. Quantified relationship between cellular radiosensitivity, DNA repair defects and chromatin relaxation: A study of 19 human tumour cell lines from different origin. Radiotherapy and Oncology 73:373-382.

Di Majo V, Rebessi S, Pazzaglia S, Saran A, Covelli V. 2003. Carcinogenesis in laboratory mice after low doses of ionizing radiation. Radiation Research 159:102-108.

Enns L, Bogen KT, Wizniak J, Murtha AD, Weinfeld M. 2004. Low-dose radiation hypersensitivity is associated with p53-dependent apoptosis. Molecular Cancer Research 2:557566

Foray N, Marot D, Gabriel A, Randrianarison V, Carr AM, Perricaudet M, Ashworth A, Jeggo P. 2003. A subset of ATM- and ATR-dependent phosphorylation events requires the BRCA1 protein. EMBO Journal 22:2860-2871. 
Friedman M. 1975. Aspects of radiation biology and radiation pathology observed during the treatment of cancer in man. British Journal of Radiology 48:81-96.

Fu KK, Phillips TL, Wharam MD. 1976. Radiation response of artificial pulmonary metastases of the EMT6 tumor. International Journal of Radiation Oncology Biology Physics 1:257260.

Harney J, Short SC, Shah N, Joiner MC, Saunders MI. 2004. Low dose hyper-radiosensitivity in metastatic tumors. International Journal of Radiation Oncology Biology Physics 59:1190-1195.

Hashimoto S, Shirato H, Hosokawa M, Nishioka T, Kuramitsu Y, Matushita K, Kobayashi M, Miyasaka K. 1999. The suppression of metastases and the change in host immune response after low-dose total body irradiation in tumor-bearing rats. Radiation Research 151:717-724.

Hosoi Y, Sakamoto K. 1993. Suppressive effect of low dose total body irradiation on lung metastasis: Dose dependency and effective period. Radiotherapy and Oncology 26:177-179.

Joiner MC, Marples B, Lambin P, Short SC, Turesson I. 2001. Low-dose hypersensitivity: Current status and possible mechanisms. International Journal of Radiation Oncology Biology Physics 49:379-389.

Joubert A, Foray N. 2006. Repair of radiation-induced DNA double-strand breaks in human cells: History, progress and controversies (Chapter 10). In: Landseer BR, editor. New research on DNA repair. Hauppauge NY: Nova Science. pp 273-294.

Joubert A, Zimmerman KM, Bencokova Z, Gastaldo J, Rénier W, Chavaudra N, Favaudon V, Arlett CF, Foray N. 2008. DNA double-strand break repair defect in syndromes associated with acute radiation response: Involvement of DNA-PK-and MRE11-dependent pathways. International Journal of Radiation Biology 84:107-125.

Klein CA, Blankenstein TJF, Schmidt-Kittler O, Perronio M, polzer B, Stoecklein NH, Riethmüller G. 2002. Genetic heterogeneity of single disseminated tumor cells in minimal residual cancer. Lancet 360:683-689.

Krueger SA, Joiner MC, Weinfeld M, Piasentin E, Marples B. 2007a. Role of apoptosis in low-dose hyper-radiosensitivity. Radiation Research 167:260-267.

Krueger SA, Collis SJ, Joiner MC, Wilson GD, Marples B. 2007b. Transition in survival from low-dose hyper-radiosensitivity to increased radioresistance is independent of activation of ATM SER1981 activity. International Journal of Radiation Oncology Biology Physics 69:1262-1271.

Kumar IP, Namita S, Goel HC. 2002. Modulation of chromatin organization by $\mathrm{RH}-3$, a preparation of Hippophae rhamnoides, a possible role in radioprotection. Molecular Cell Biochemistry 238:1-9.

Lambin P, Fertil B, Malaise EP, Joiner MC. 1994. Multiphasic survival curves for cells of human tumor cell lines: induced repair or hypersensitive subpopulation? Radiation Research 138:S32-36.

Liu SZ. 2003. On radiation hormesis expressed in the immune system. Critical Review in Toxicology 33:431-441.

Malyapa RS, Bi C, Ahern EW, Roti Roti JL. 1998. Detection of DNA damage by the alkaline comet assay after exposure to low-dose gamma radiation. Radiation Research 149:396400.

Marples B, Wouters BG, Joiner MC. 2003. An association between the radiation-induced arrest of $\mathrm{G}_{2}$-phase cells and low-dose hyper-radiosensitivity: A plausible underlying mechanism? Radiation Research 160:38-45.

Marples B, Wouters BG, Collis SJ, Chalmers AJ, Joiner MC. 2004. Low-dose hyper-radiosensitivity: A consequence of ineffective cell cycle arrest of radiation-damaged $G_{2}$-phase cells. Radiation Research 161:247-255.
Martin F, Caignard A, Jeannin JF, Leclerc A, Martin M. 1983. Selection by trypsin of two sublines of rat colon cancer cells forming progressive or regressive tumors. International Journal of Cancer 32:623-627.

Meehan KA, Truter EJ, Slabbert JP, Parker MI. 2004. Evaluation of DNA damage in a population of bats (Chiroptera) residing in an abandoned monoazite mine. Mutation Research 557:183-190.

Olive PL, Frazer G, Banath JP. 1993. Radiation-induced apoptosis measured in TK6 human B lymphoblast cells using the comet assay. Radiation Research 136:130-136.

Portless DL, Bauer G, Hill MA, O’Neil P. 2007. Low-dose irradiation of nontransformed cells stimulates the selective removal of precancerous cells via intercellular induction of apoptosis. Cancer Research 67:1246-1253.

Puvion-Dutilleul F, Sarasin A. 1989. Chromatin and nucleolar changes in Xeroderma pigmentosum cells resemble agingrelated nuclear events. Mutation Research 219:57-70.

Raderschall E, Golub EI, Haff T. 1999. Nuclear foci of mammalian recombination proteins are located at singlestranded DNA regions formed after DNA damage. Proceeding of the National Academy of Sciences USA 96:1921-1926.

Rao BR, Slotman BJ, Geldof AA, Perez CA. 1991. Radiation sensitivity of Copenhagen rat prostatic carcinoma (R3327-AT and R3327-MATLyLu). International Journal of Radiation Oncology Biology Physics 20:981-985.

Redpath JL, Short SC, Woodcock M, Johnston PJ. 2003. Lowdose reduction in transformation frequency compared to unirradiated controls: the role of hyper-radiosensitivity to cell death. Radiation Research 159:433-436.

Rothkamm K, Löbrich M. 2003. Evidence for a lack of DNA double-strand break repair in human cells exposed to very low $\mathrm{X}$-ray doses. Proceedings of the National Academy of Sciences, USA 100:5057-5062.

Schlegel BP, Jodelka FM, Numez R. 2006. BRCA1 promotes induction of ssDNA by ionizing radiation. Cancer Research 66:5181-5189.

Schultz N, Lopez E, Saleh-Gohari N, Helleday T. 2003. Poly(ADP-ribose) polymerase (PARP-1) has a controlling role in homologous recombination. Nucleic Acid Research 31:4959-4964.

Short SC, Bourne S, Martindale C, Woodcock M, Jackson SP. 2005. DNA damage responses at low radiation doses. Radiation Research 164:292-302.

Skov KA. 1999. Radioresponsiveness at low doses: hyper-radiosensitivity and increased radioresistance in mammalian cells. Mutation Research 430:241-253.

Slonina D, Biesaga B, Urbanski K, Kojs Z. 2007. Low-dose radiation response of primary keratinocytes and fibroblasts from patients with cervix cancer. Radiation Research 167:251259.

Thomas C, Buronfosse A, Portoukalian J, Fertil B. 1997. The gangliosides as a molecular coupling factor between the proportion of radiosensitive cells in vitro and the metastatic potential in vivo within a human melanoma cell line. British Journal of Cancer 75:639-649.

Thomas C, Buronfosse A, Courdi A, Fertil B. 2001. Radio-prevention of micrometastasis. Medical Hypotheses 57:398-404.

Thomas C, Fertil B, Foray N. 2007. Very low-dose hyperradiosensitivity: Impact for radiotherapy of micrometastases. Cancer/Radiothérapie 11:260-265.

Tortola S, Steinert R, Hantschick M, Peinado MA, Gastinger I, Stosiek P, Lippert H, Schegel W, Raymond MA. 2001. Discordance between K-ras mutations in bone marrow micrometastases and the primary tumor in colorectal cancer. Journal of Clinical Oncology 19:2837-2843. 
Vaganay-Juery S, Muller C, Marangoni B, Abdulkarim B, Deutsch E, Lambin P, Calsou P, Eschwege F, Salles B, Joiner MC, Bourhis J. 2000. Decreased DNA-PK activity in human cancer cells exhibiting hypersensitivity to low-dose irradiation. British Journal of Cancer 283:514-518.

Welch DR, Milas L, Tomasovic SP, Nicolson GL. 1983. Heterogeneous response and clonal drift of sensitivities of metastatic $13762 \mathrm{NF}$ mammary adenocarcinoma clones to $\gamma$ radiation in vitro. Cancer Research 43:6-10.
Wykes SM, Piasentin E, Joiner MC, Wilson GD, Marples B. 2006. Low-dose hyper-radiosensitivity is not caused by a failure to recognize DNA double-strand breaks. Radiation Research 165:516-524. 